\title{
Synthesis of Paramagnetic Tetranuclear Rhodium and Iridium Complexes with the 2,6-Pyridinedithiolate Ligand. Redox-Induced Degradation to Diamagnetic Triiridium Compounds
}

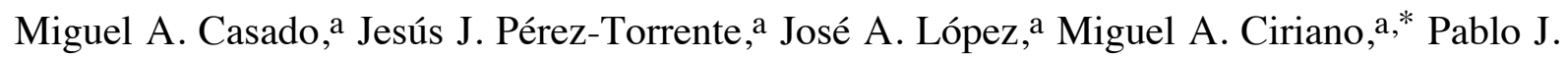
Alonso, ${ }^{\mathrm{b}}$ Fernando J. Lahoz, ${ }^{\mathrm{a}}$ and Luis A. Oro ${ }^{\mathrm{a}},{ }^{*}$

a Departamento de Química Inorgánica, Instituto de Ciencia de Materiales de Aragón, Universidad de Zaragoza-C.S.I.C., E-50009 Zaragoza, Spain.

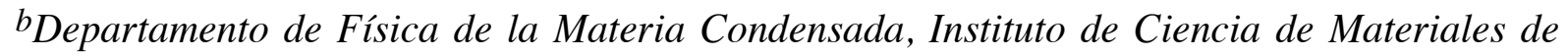
Aragón, Universidad de Zaragoza-C.S.I.C., E-50009 Zaragoza, Spain. 


\section{Abstract}

The tetranuclear complexes $\left.\left[\mathrm{M}_{4}\left(\mu-\mathrm{PyS}_{2}\right)_{2} \text { (diolefin }\right)_{4}\right]\left[\mathrm{PyS}_{2}=2,6\right.$-pyridinedithiolate; $\mathrm{M}=\mathrm{Rh}, \quad$ diolefin $\quad=\operatorname{cod}(1,5$-cyclooctadiene $) \quad(\mathbf{1}), \quad \mathrm{tfbb}$ (tetrafluorobenzo[5,6]bicyclo[2.2.2]octa-2,5,7-triene) (2); M = Ir, diolefin = cod (3), tfbb (4)] exhibit two one-electron oxidations at a platinum disk electrode in dichloromethane at potentials accessible by chemical reagents. The rhodium tetranuclear complexes were selectively oxidized to the monocationic complexes $\left[\mathrm{Rh}_{4}\left(\mu-\mathrm{PyS}_{2}\right)_{2}(\text { diolefin })_{4}\right]^{+}\left(\mathbf{1}^{+}, \mathbf{2}^{+}\right)$by mild one-electron oxidants such as $\left[\mathrm{Cp}_{2} \mathrm{Fe}\right]^{+}$or $\left[\mathrm{N}\left(\mathrm{C}_{6} \mathrm{H}_{4} \mathrm{Br}-4\right)_{3}\right]^{+}$, and isolated as the $\mathrm{PF}_{6}^{-}$, $\mathrm{BF}_{4}^{-}$and $\mathrm{ClO}_{4}^{-}$salts. Silver salts behave as non innocent one-electron oxidants for the reactions with the rhodium complexes $\mathbf{1}$ and $\mathbf{2}$ since they give sparingly soluble coordination polymers. The complex $\left[\operatorname{Ir}_{4}\left(\mu-\mathrm{PyS}_{2}\right)_{2}(\operatorname{cod})_{4}\right]^{+}\left(3^{+}\right)$was obtained as the tetrafluoroborate salt by reaction of 3 with one molar-equiv of $\mathrm{AgBF}_{4}$, but the related complex complex $\mathbf{4}^{+}$could not be isolated from the chemical oxidation of $\left[\operatorname{Ir}_{4}\left(\mu-\mathrm{PyS}_{2}\right)_{2}(\mathrm{tfbb})_{4}\right]$ (4) with $\mathrm{AgBF}_{4}$. Oxidation of $\mathbf{3}$ and $\mathbf{4}$ with two molar-equiv of common silver salts resulted in the fragmentation of the complexes to give the diamagnetic triiridium cations $\left[\operatorname{Ir}_{3}(\mu-\right.$ $\left.\left.\mathrm{PyS}_{2}\right)_{2}(\text { diolefin })_{3}\right]^{+}$. The molecular structure of $\left[\operatorname{Ir}_{3}\left(\mu-\mathrm{PyS}_{2}\right)_{2}(\operatorname{cod})_{3}\right] \mathrm{BF}_{4}$, determined by Xray diffraction methods, showed the three metal atoms within an angular arrangement. Both 2,6-pyridinedithiolate tridentate ligands bridge two metal-metal bonded $\mathrm{d}^{7}$ centers in pseudo octahedral environments and one $\mathrm{d}^{8}$ square-planar iridium center. An interpretation of the EPR spectra of the 63-electron mixed-valence paramagnetic tetranuclear complexes suggests that the unpaired electron is delocalized over two of the metal atoms in the complexes $\mathbf{1}^{+}-\mathbf{3}^{+}$.

\section{Introduction}

The study of the electrochemical behavior of polymetallic compounds is a field of great potential interest directly related to molecular biology, electrosynthesis, electrocatalysis or new ionic materials with potential electronic and magnetic properties. ${ }^{1}$ Transition metal clusters are able to adopt a range of formal valence states and usually undergo several reversible one-electron processes. Although metallic clusters frequently behave as electron reservoirs, ${ }^{2}$ a series of metal carbonyl clusters displaying electron-sink features, comparable 
to Fe-S cubane clusters, have been very recently reported. ${ }^{3}$ The structural effects following the redox changes in clusters are quite unpredictable. The changes in the metal-metal bond distances are generally consequence of the reversible loss or gain of electrons and encompass metal-metal bond formation or rupture, isomerization and rearrangement processes. ${ }^{4}$ Irreversible redox steps are frequently associated to cluster fragmentation after the electron exchange although cluster fragments of lower nuclearity have rarely been characterized. 5 Noteworthy, the metal core cohesion may be reinforced towards fragmentation by chelating and bridging ligands. 6 Polynuclear complexes supported by highly flexible bridging ligands are closely related to clusters in spite of lacking metal-metal bonds. As the metals are hold in proximity, the possibility of metal-metal bond formation is still open by the flexibility of the molecular framework to adapt both to variations of metal-metal separation and to the coordination geometries about the metal atoms. ${ }^{7}$ The redox chemistry of tetra-bridged dinuclear $\mathrm{Rh}(\mathrm{II})-\mathrm{Rh}(\mathrm{II})$ complexes of the type $\left[\mathrm{Rh}_{2}(\mu-\mathrm{Y})_{4}\right](\mathrm{Y}=\mathrm{O}, \mathrm{O}-, \mathrm{O}, \mathrm{N}-, \mathrm{N}, \mathrm{S}-, \mathrm{N}, \mathrm{N}-$ donor, etc.) ${ }^{8}$ and of di-bridged $\mathrm{M}(\mathrm{I})-\mathrm{M}(\mathrm{I})$ compounds $\left[\mathrm{M}_{2}(\mu-\mathrm{Y})_{2} \mathrm{~L}_{4}\right](\mathrm{M}=\mathrm{Rh}, \mathrm{Ir})^{9,10}$ has been studied in considerable detail. In contrast, less attention has been paid to the redox chemistry of tri- and tetranuclear rhodium and iridium complexes although they are expected to act as precursors for multi-electron-transfer processes. ${ }^{11,12}$

We have prepared a variety of polynuclear complexes with bridging ligands having a $\mathrm{N}-\mathrm{C}-\mathrm{X}(\mathrm{X}=\mathrm{N}, \mathrm{O}, \mathrm{S})$ structural donor unit, ${ }^{13}$ and in particular, a new family of tetranuclear rhodium and iridium aggregates supported by two tridentate 2,6-pyridinedithiolate bridging ligands of general formula $\left.\left[\mathrm{M}_{4}\left(\mu-\mathrm{PyS}_{2}\right)_{2} \text { (diolefin) }\right)_{4}\right]{ }^{14}$ These compounds undergo two consecutive and reversible one-electron oxidations, although the electrochemical behavior of the iridium complexes is more complicated, and we report here on their chemical oxidation leading to stable paramagnetic and diamagnetic polynuclear complexes.

\section{Results}

Synthesis and electrochemical properties of $\left[\operatorname{Ir}_{4}\left(\mu-\mathbf{P y S}_{2}\right)_{2}(\mathbf{t f b b})_{4}\right]$. The tetranuclear complex $\quad\left[\operatorname{Ir}_{4}\left(\mu-\mathrm{PyS}_{2}\right)_{2}(\mathrm{tfbb})_{4}\right]$

(4) $\quad\left(\mathrm{PyS}_{2}=\right.$ 2,6-pyridinedithiolate; $\mathrm{tfbb}=$ tetrafluorobenzo[5,6]bicyclo[2.2.2]octa-2,5,7-triene) has been synthesized for comparative 
purposes following the procedure described for the related complexes $\left[\mathrm{M}_{4}(\mu\right.$ $\left.\left.\mathrm{PyS}_{2}\right)_{2}(\text { diolefin })_{4}\right][\mathrm{M}=\mathrm{Rh}$, diolefin $=\operatorname{cod}(1,5$-cyclooctadiene $)(\mathbf{1}), \mathrm{tfbb}(\mathbf{2}) ; \mathrm{M}=\mathrm{Ir}$, diolefin $=\operatorname{cod}(\mathbf{3})] \cdot{ }^{14}$ The molecular ion $\mathbf{4}^{+}(\mathrm{m} / \mathrm{z}: 1956,100 \%)$ was observed in the $\mathrm{FAB}^{+}$mass spectrum, and the structure of the compound was found to be similar to those of the related tetranuclear complexes 1-3 (Figure 1), since the ${ }^{1} \mathrm{H}$ NMR spectrum is consistent with a $\mathrm{C}_{2}$ symmetry.

The cyclic voltammogram (CV) of complex 4 (Figure 2) recorded in dichloromethane at $100 \mathrm{mVs}^{-1}$ shows two waves at 0.19 and $0.62 \mathrm{~V}$, and an anodic peak at $1.15 \mathrm{~V}$ versus the SCE. The first is reversible and it is associated to the electrogeneration of the monocationic species $\left[\operatorname{Ir}_{4}\left(\mu-\mathrm{PyS}_{2}\right)_{2}(\mathrm{tfbb})_{4}\right]^{+}$, while the second wave is not reversible and is associated to a product with a irreversible catodic peak at $c a .-0.30 \mathrm{~V}$. The potential of the second wave is close to those of the formal electrode potentials for the electrochemical process $\left[\mathrm{M}_{4}\right]^{+} \rightarrow\left[\mathrm{M}_{4}\right]^{2+}$ undergone by the complexes 1-3. The formal electrode potentials are strongly dependent on the nature both of the metallic centers and the diolefin ligands (Table 1). Thus, for the tfbb complexes $\mathbf{2}$ and $\mathbf{4}$ they are anodically shifted relative to those observed for the cod complexes $\mathbf{1}$ and $\mathbf{3}$, respectively, in agreement with the stronger $\pi$-acceptor character of the tfbb ligands. On the other hand, the reversible oxidations of the iridium complexes $\mathbf{3}$ and $\mathbf{4}$ are found at lower formal electrode potentials relative to those observed for the rhodium complexes $\mathbf{1}$ and $\mathbf{2}$, respectively, indicating that the iridium complexes are easier to oxidize than the related rhodium complexes. The difference between the formal potentials of both oxidation processes in the tetranuclear complexes is large enough $(0.42-0.45 \mathrm{~V})$ to propose that the monocationic $\left[\mathrm{M}_{4}\right]^{+}$compounds should be stable to disproportionation to the neutral $\left[\mathrm{M}_{4}\right]$ and dicationic $\left[\mathrm{M}_{4}\right]^{2+}$ species. In fact, the calculated $\mathrm{K}_{\mathrm{disp}}$ values ${ }^{12,15}$ for the disproportionation equilibria $\left(8.3 \times 10^{-8}\right.$ for $\mathbf{1 - 2}, 2.4 \times 10^{-8}$ for $\left.\mathbf{3}\right)$ strongly suggest to attempt their chemical synthesis.

\section{Chemical Oxidations of the Rhodium Complexes $\left[\mathrm{Rh}_{4}\left(\mu-\mathrm{PyS}_{2}\right)_{2}(\text { diolefin })_{4}\right]$. Synthesis} and Characterization of the Cationic Complexes $\left[\operatorname{Rh}_{4}\left(\mu-P_{1} S_{2}\right)_{2}(\text { diolefin })_{4}\right]^{+}\left(1^{+}, 2^{+}\right)$

The reactions of the complexes $\left.\left[\mathrm{Rh}_{4}\left(\mu-\mathrm{PyS}_{2}\right)_{2} \text { (diolefin }\right)_{4}\right](\mathbf{1}, \mathbf{2})$ with $\left[\mathrm{Cp}_{2} \mathrm{Fe}_{\mathrm{PF}} \mathrm{PF}_{6}\right.$ in dichloromethane (1:1 molar ratio) gave the cationic complexes $\left[\mathrm{Rh}_{4}\left(\mu-\mathrm{PyS}_{2}\right)_{2}(\mathrm{cod})_{4}\right] \mathrm{PF}_{6}$ 
$\left(\mathbf{1 a}^{+}\right)$and $\left[\mathrm{Rh}_{4}\left(\mu-\mathrm{PyS}_{2}\right)_{2}(\mathrm{tfbb})_{4}\right] \mathrm{PF}_{6}\left(\mathbf{2 a}^{+}\right)$, which were isolated as dark brown and green solids, respectively, in excellent yields. Complex $\mathbf{1 a}^{+}$can be alternatively prepared by oxidation of 1 with the salt of the triarylaminium radical cation $\left[\mathrm{N}\left(\mathrm{C}_{6} \mathrm{H}_{4} \mathrm{Br}-4\right)_{3}\right] \mathrm{PF}_{6} \cdot{ }^{16} \mathrm{In}$ an attempt to grow good quality monocrystals we have isolated several salts of the cationic complexes $\mathbf{1}^{+}$and $\mathbf{2}^{+}$with a variety of counteranions. The compounds $\left[\mathrm{Rh}_{4}\left(\mu-\mathrm{PyS}_{2}\right)_{2}(\operatorname{cod})_{4}\right] \mathrm{X}$ $\left(\mathrm{X}=\mathrm{PF}_{6}, \mathbf{1 a}^{+} ; \mathrm{BF}_{4}, \mathbf{1 b}^{+} ; \mathrm{ClO}_{4}, \mathbf{1 c}^{+}\right)$and $\left[\mathrm{Rh}_{4}\left(\mu-\mathrm{PyS}_{2}\right)_{2}(\mathrm{tfbb})_{4}\right] \mathrm{X}\left(\mathrm{X}=\mathrm{PF}_{6}, \mathbf{2} \mathbf{a}^{+} ; \mathrm{BF}_{4}, \mathbf{2} \mathbf{b}^{+}\right.$; $\mathrm{ClO}_{4}, \mathbf{2} \mathbf{c}^{+}$) are easily accessible by reaction of $\mathbf{1}$ and $\mathbf{2}$ with freshly made blue solutions of the appropriate ferrocenium salt, $\left[\mathrm{Cp}_{2} \mathrm{Fe}\right] \mathrm{X}$, prepared in situ. Solutions of the oxidants $\left[\mathrm{FeCp}_{2}\right] \mathrm{X}$ $\left(\mathrm{X}=\mathrm{PF}_{6}^{-}, \mathrm{BF}_{4}^{-}\right.$or $\left.\mathrm{ClO}_{4}^{-}\right)$are easily obtained by reaction of different silver salts $\mathrm{AgX}$ with an excess of ferrocene in acetone after removing the grey precipitate of metallic silver. ${ }^{17}$ (WARNING: $\mathrm{AgClO}_{4}$ and $\left[\mathrm{Cp}_{2} \mathrm{Fe}\right] \mathrm{ClO}_{4}$ are explosive and treacherous materials that should be handle with great caution and in small amounts, as well as the perchlorate salts of metal complexes with organic ligands).

The paramagnetic complexes $\mathbf{1 a}^{+}$and $\mathbf{2 a}^{+}$have been characterized by elemental analyses, $\mathrm{FAB}^{+}$, voltammetry and EPR spectroscopy. The $\mathrm{FAB}^{+}$mass spectra of $\mathbf{1} \mathbf{a}^{+}$and $\mathbf{2 a}^{+}$ show peaks at m/z: $1126(100 \%)$ and $1598(100 \%)$, corresponding to the molecular ions $\left[\mathrm{Rh}_{4}\left(\mu-\mathrm{PyS}_{2}\right)_{2}(\mathrm{cod})_{4}\right]^{+}$and $\left[\mathrm{Rh}_{4}\left(\mu-\mathrm{PyS}_{2}\right)_{2}(\mathrm{tfbb})_{4}\right]^{+}$, respectively. The ionic character of $\mathbf{1}^{+}$ and $2^{+}$is supported by conductivity measurements in acetone where they behave as 1:1 electrolytes. Linear voltammetry at rotating platinum electrode (RDE) and EPR spectroscopy provide conclusive evidence for the formulation of complexes $\mathbf{1}^{+}$and $\mathbf{2}^{+}$as paramagnetic mono-oxidized species. For example, the cyclic voltammogram of $\left[\mathrm{Rh}_{4}(\mu-\right.$ $\left.\left.\mathrm{PyS}_{2}\right)_{2}(\operatorname{cod})_{4}\right] \mathrm{PF}_{6}\left(\mathbf{1 a}^{+}\right)$in dichloromethane exhibits one reduction wave and one oxidation wave at potentials vitually identical to those for the parent tetranuclear complex $\mathbf{1}$. Furthermore, the linear voltammograms at RDE show two characteristic steps but the sign of the current is negative for the first process and positive for the second, which confirms both the identity and the purity of the mono-oxidized species.

The X-band Electron Paramagnetic Resonance (EPR) spectrum of a solid crystalline sample of $\mathbf{1 a}^{+}$consists of a slightly asymmetric line centered at about $g=2.20$. When 
measured at Q-band, three clearly resolved features can be observed (Figure 3a). This spectrum can be described as due to an $S=1 / 2$ entity and the following spin-Hamiltonian:

$$
H=\mu_{B} B\left\{g_{x} l_{x} S_{x}+g_{y} l_{y} S_{y}+g_{z} l_{z} S_{z}\right\}
$$

where $\mu_{B}$ is the Bohr magneton and $l_{x}, l_{y}, l_{z}$ are the director cosines that the magnetic field makes with the principal axis of the $g$-tensor for which the principal values are $g_{x}, g_{y}, g_{z} . \mathrm{A}$ simulation of the signal with $g_{x}=2.072 \pm 0.005, g_{y}=2.174 \pm 0.005, g_{z}=2.233 \pm 0.005$ and a Lorentzian line shape (with the band halfwidth $W_{x}=10.0 \mathrm{mT}, W_{y}=2.8 \mathrm{mT}, W_{z}=17.5 \mathrm{mT}$ ) gave an excellent agreement between the calculated and experimental spectra (Figure 3 a). Then, the trace of the $g$-tensor, $g=\left(g_{x}+g_{y}+g_{z}\right) / 3$ resulted to be $2.16 \pm 0.01$. The EPR spectrum of $\mathbf{2} \mathbf{b}^{+}$is similar to the former and can also be described with the spin-Hamiltonian given above with $g_{x} \approx g_{y}=2.088 \pm 0.005, g_{z}=2.155 \pm 0.005 ; \mathrm{g}=2.11 \pm 0.01$. No hyperfine structure was observed again. However, the EPR spectrum of $\mathbf{1 a}^{+}$measured in X-band on a frozen dichloromethane:THF 2:1 solution at $90 \mathrm{~K}$ showed the signal at high field as a broad triplet (Figure $3 \mathrm{~b}$ ), indicative of the coupling with two equivalent $\mathrm{Rh}$ nuclei $\left({ }^{103} \mathrm{Rh}\right.$ nuclear spin $I=1 / 2)$. Simulation of the signal with $g_{x}=2.063 \pm 0.005, g_{y}=2.178 \pm 0.005, g_{z}=2.249$ \pm 0.005 , a Gaussian line shape (with the band halfwith $W_{x}=1.4 \mathrm{mT}, W_{y}=3.1 \mathrm{mT}, W_{z}=2.5$ $\mathrm{mT}$, and a coaxial hyperfine coupling $A_{x}=1.7 \mathrm{mT}, A_{y} \approx 0 \mathrm{mT}, A_{z} \approx 0 \mathrm{mT}$ ) gave an excellent agreement with the experimental data.

The synthesis of the dicationic complexes $\left[\operatorname{Rh}_{4}\left(\mu-\mathrm{PyS}_{2}\right)_{2}(\text { diolefin })_{4}\right]^{2+}\left(\mathbf{1}^{2+}\right.$ and $\left.\mathbf{2}^{2+}\right)$ was attempted using silver salts as chemical oxidants. When complexes $\mathbf{1}$ and $\mathbf{2}$ were reacted with one molar-equiv of a soluble silver salt in an acetone-dichloromethane mixture resulted insoluble purple solids, which are probably coordination polymers, ${ }^{18}$ without formation of metallic silver. Silver salts behave thus as non innocent one-electron oxidants. However, when complex 1 was reacted with two molar-equiv of $\mathrm{AgBF}_{4}$ an oxidation process resulted evident, since a dark suspension containing metallic silver was immediately formed. Interestingly, the brown solid isolated from the solution was found to be identical to that obtained from the reaction of the mono-oxidized complex $\mathbf{1 b}^{+}$with only one molar-equiv of $\mathrm{AgBF}_{4}$. The linear voltammogram at RDE of the brown solid clearly indicates that it is a mixture of $\mathbf{1 b}^{+}$and other highly oxidized species. The $\mathrm{FAB}^{+}$mass spectrum of this solid 
shows the peak corresponding to the tetranuclear ion $\left[\mathrm{Rh}_{4}\left(\mu-\mathrm{PyS}_{2}\right)_{2}(\operatorname{cod})_{4}\right]^{+}$, but the conductivity measurements in acetone lie in the range of 1:2 electrolytes. Surprisingly, the EPR spectrum of this solid is similar to that of $\mathbf{1 a}^{+}$, and can be described with the same spinHamiltonian and $g_{x}=2.078 \pm 0.005, g_{y}=2.187 \pm 0.005, g_{z}=2.240 \pm 0.005(\mathrm{~g}=2.17 \pm$ 0.01 ), which suggest that if $\mathbf{1}^{2+}$ were in the mixture it would be diamagnetic.

The chemical oxidation of the complex 2 required two molar-equiv of $\mathrm{AgBF}_{4}$ to give the heteropolynuclear complex $\left[\mathrm{AgRh}_{4}\left(\mu-\mathrm{PyS}_{2}\right)_{2}(\mathrm{tfbb})_{4}\right]\left(\mathrm{BF}_{4}\right)_{2}$ instead of the expected oxidized complex $\mathbf{2}^{2+}$. This compound was isolated as an air-sensitive purple paramagnetic solid and the formulation is supported by the $\mathrm{FAB}^{+}$mass spectrum, which showed an intense peak at m/z: 1705 with the right isotopic distribution. The EPR spectrum, measured in X-band at room temperature, showed a single Lorenztian line centered at about $g=2.11$ with a peak to peak width of $5.2 \mathrm{mT}$. This g-value strongly suggests that the unpaired electron is located on the rhodium atoms. The ionic character of this compound was confirmed by conductivity measurements in acetone, but we have been unable to obtain satisfactory elemental analyses. We believe that the species $\left[\mathrm{AgRh}_{4}\left(\mu-\mathrm{PyS}_{2}\right)_{2}(\mathrm{tfbb})_{4}\right]^{2+}$ could be structurally related to the heteropentanuclear complex $\left[\mathrm{TIRh}_{4}\left(\mu-\mathrm{PyS}_{2}\right)_{2}(\mathrm{cod})_{4}\right]^{+}$, resulting from the encapsulation of $\mathrm{Tl}^{+}$ion by the tetranuclear complex $\mathbf{1},{ }^{19}$ since this compound is also obtained directly from the reaction of the complex $\left[\mathrm{Rh}_{4}\left(\mu-\mathrm{PyS}_{2}\right)_{2}(\mathrm{tfbb})_{4}\right]^{+}\left(\mathbf{2 b}^{+}\right)$with $\mathrm{AgBF}_{4}$.

\section{Chemical Oxidations of the Iridium Complexes $\left[\operatorname{Ir}_{4}\left(\mu-P_{y} S_{2}\right)_{2}(\text { diolefin })_{4}\right]$. Redox- Induced Degradation of the Tetranuclear Framework.}

Reaction of the complex $\left[\operatorname{Ir}_{4}\left(\mu-\mathrm{PyS}_{2}\right)_{2}(\mathrm{cod})_{4}\right](3)$ with one molar-equiv of $\mathrm{AgBF}_{4}$ in dichloromethane/acetone produces a clean oxidation to the paramagnetic complex $\left[\operatorname{Ir}_{4}(\mu-\right.$ $\left.\left.\mathrm{PyS}_{2}\right)_{2}(\operatorname{cod})_{4}\right] \mathrm{BF}_{4}\left(\mathbf{3}^{+}\right)$and metallic silver. Complex $\left(\mathbf{3}^{+}\right)$was isolated in high yield as a green microcrystalline air-sensitive solid and behaves as a 1:1 electrolyte in acetone. Moreover, the purity of $\mathbf{3}^{+}$was unequivocally established electrochemically by linear voltammetry at RDE. The Q-band EPR spectrum of a polycrystalline sample of $\mathbf{3}^{+}$at low temperature can be described using the above introduced spin-Hamiltonian with $g_{x}=2.097 \pm 0.005, g_{y}=2.213 \pm$ $0.005, g_{z}=2.407 \pm 0.005 ; \mathrm{g}=2.24 \pm 0.01$. No hyperfine structure was observed for a polycrystalline sample nor for a frozen solution in dichloromethane:THF 2:1 at $90 \mathrm{~K}$. 
An unexpected fragmentation of the tetranuclear framework occurred on oxidation of complex 3 with two molar-equiv of $\mathrm{AgBF}_{4}$ in dichloromethane/acetone to give the trinuclear complex $\left[\operatorname{Ir}_{3}\left(\mu-\mathrm{PyS}_{2}\right)_{2}(\operatorname{cod})_{3}\right] \mathrm{BF}_{4}(\mathbf{5 b})$ and metallic silver. Complex $\mathbf{5 b}$ was isolated as a violet air-stable microcrystalline solid. This redox induced degradation of the tetranuclear framework can be accomplished stepwise to give $\mathbf{3}^{+}$in a first place, and then a further addition of one molar-equiv of $\mathrm{AgBF}_{4}$ or even reaction of $\mathbf{3}^{+}$with molecular oxygen gives $\mathbf{5 b}$. (Scheme 1). Interestingly, the oxidation of $\mathbf{3}$ with two molar-equiv of $\left[\mathrm{N}\left(\mathrm{C}_{6} \mathrm{H}_{4} \mathrm{Br}-4\right)_{3}\right] \mathrm{PF}_{6}$ to give the hexafluorophosphate salt $\left[\operatorname{Ir}_{3}\left(\mu-\mathrm{PyS}_{2}\right)_{2}(\operatorname{cod})_{3}\right] \mathrm{PF}_{6}(\mathbf{5 a})$ proceeds cleanly with a considerable increase in the yield relative to the oxidation with the silver salt.

The paramagnetic complex $\left[\operatorname{Ir}_{4}\left(\mu-\mathrm{PyS}_{2}\right)_{2}(\mathrm{tfbb})_{4}\right]^{+}\left(\mathbf{4}^{+}\right)$was not accessible by chemical oxidation of the compound $\left[\operatorname{Ir}_{4}\left(\mu-\mathrm{PyS}_{2}\right)_{2}(\mathrm{tfbb})_{4}\right](4)$ with one molar-equiv of $\mathrm{AgBF}_{4}$. This reaction gave directly an equimolar mixture of $\mathbf{4}$ and the trinuclear complex $\left[\operatorname{Ir}_{3}(\mu\right.$ $\left.\left.\mathrm{PyS}_{2}\right)_{2}(\mathrm{tfbb})_{3}\right] \mathrm{BF}_{4}(\mathbf{6})\left({ }^{1} \mathrm{H} \mathrm{NMR}\right.$ evidence). Complex 6, resulting from the fragmentation of the tetranuclear complex, was also obtained from the reaction of complex $\mathbf{4}$ with two molarequiv of $\mathrm{AgBF}_{4}$, and was isolated as a dark green air stable solid in moderate yield.

The diamagnetic complexes $\mathbf{5}$ and $\mathbf{6}$ were characterized by elemental analyses, mass spectra and ${ }^{1} \mathrm{H}$ NMR spectroscopy, while $\left[\operatorname{Ir}_{3}\left(\mu-\mathrm{PyS}_{2}\right)_{2}(\operatorname{cod})_{3}\right] \mathrm{BF}_{4} \quad(\mathbf{5 b})$ was fully characterized by X-ray methods (see below). They maintain the structure in solution since both 2,6-pyridinedithiolate ligands and all the olefinic protons of the three coordinated diolefins are inequivalent in the ${ }^{1} \mathrm{H}$ NMR spectra, in agreement with the lack of symmetry of the complexes.

It is interesting to notice that the 62-electron dicationic species $\left[\operatorname{Ir}_{4}(\mu\right.$ $\left.\left.\mathrm{PyS}_{2}\right)_{2}(\text { diolefin })_{4}\right]^{2+}$ were not isolated from the chemical oxidation of complexes $\mathbf{3}$ and $\mathbf{4}$ with silver salts. In this context it is worthy to mention that the $\mathrm{CV}$ profile of $\left[\operatorname{Ir}_{3}(\mu-\right.$ $\left.\mathrm{PyS}_{2}\right)_{2}(\mathrm{cod})_{3} \mathrm{BF}_{4}(\mathbf{5 b})$ (consisting of four irreversible processes: an anodic peak at $0.99 \mathrm{~V}$ and catodic peaks at $0.73,-0.37$ and $-1.12 \mathrm{~V}$ at $100 \mathrm{mVs}^{-1}$ ) is observed in the $\mathrm{CV}$ of complex $\left[\operatorname{Ir}_{4}\left(\mu-\mathrm{PyS}_{2}\right)_{2}(\operatorname{cod})_{4}\right](\mathbf{3}),{ }^{14}$ indicating that $\mathbf{5 b}$ is also electrochemically generated after the two-electron oxidation of 3 . Therefore, the 62-electron dicationic species $\left[\operatorname{Ir}_{4}(\mu\right.$ $\left.\left.\mathrm{PyS}_{2}\right)_{2}(\text { diolefin })_{4}\right]^{2+}$ probably mediate the degradation of the tetranuclear complexes in both 
cases. Taking into account that the trinuclear complexes $\left[\operatorname{Ir}_{3}\left(\mu-\mathrm{PyS}_{2}\right)_{2}(\text { diolefin })_{3}\right]^{+}(\mathbf{5 - 6})$ are 50-electron clusters, their formation involves the formal extrusion of the 12-electron fragment $[\operatorname{Ir}(\text { diolefin })]^{+}$from the oxidized species $\left[\operatorname{Ir}_{4}\left(\mu-\mathrm{PyS}_{2}\right)_{2}(\text { diolefin })_{4}\right]^{2+}$. The fate of these hypothetical fragments is unknown, since we have not been able to capture them as defined complexes by adding bidentate ligands, such as triphenylphosphine or 2,2'-bipyridine, to the solutions resulting from the isolation of the trinuclear complexes.

Molecular structure of $\left[\operatorname{Ir}_{3}\left(\mu-P_{y} S_{2}\right)_{2}(\operatorname{cod})_{3}\right] \mathbf{B F}_{4}(5 b)$. Figure 5 shows a representation of the trinuclear cation together with the atom labeling scheme used, and Table 2 displays selected bond distances and angles. The complex cation is formed by three iridium atoms, three cyclooctadiene molecules -each one chelated to a different metal center-, and two 2,6pyridinedithiotale groups, bonded to the iridium atoms through the pyridine nitrogen and the sulfur atoms in a non symmetric way. One of these two bridging ligands (see Figure 5) is coordinated in a chelate fashion through $S(1)$ and $N(1)$ to $\operatorname{Ir}(1)$, while $S(2)$ presents a $\mu^{2}$ coordination to both $\operatorname{Ir}(2)$ and $\operatorname{Ir}(3)$. The other 2,6-pyridinedithiotale group is bonded through $S(3)$ to $\operatorname{Ir}(3)$, through $N(4)$ to $\operatorname{Ir}(2)$, and through $S(4)$ to $\operatorname{Ir}(1)$ and $\operatorname{Ir}(2)$ in such a way that the three iridium atoms present distinct coordination spheres. $\operatorname{Ir}(3)$ is disposed in a square-planar environment, usual for a $\mathrm{d}^{8}$ metal, linked to $\mathrm{S}(2), \mathrm{S}(3)$ and the two olefinic bonds of a cyclooctadiene molecule. The other two iridium atoms present more complex environments, with a intermetallic length $(\operatorname{Ir}(1)-\operatorname{Ir}(2)=2.9509(6) \AA)$ suggesting the existence of a metalmetal bond. This distance is rather long for a Ir-Ir bond, but larger intermetallic bond lengths have been reported for $\mathrm{d}^{7}-\mathrm{d}^{7}$ iridium complexes such as $\left[\operatorname{IrCl}(\mathrm{CO})\left(\mathrm{C}\left(\mathrm{CO}_{2} \mathrm{Me}\right)=\mathrm{CHCO}_{2} \mathrm{Me}\right)(\mathrm{dppm})_{2}\right]_{2}(3.0128$ and $3.0216(10) \AA),{ }^{20}$ and $\left[\operatorname{Ir}_{2}(\mu-\mathrm{Pz})_{2}\right.$ $\left.(\operatorname{cod})_{2}(\mathrm{I})(\mathrm{Me})\right](3.112(1) \AA)^{21}$

From a geometric viewpoint, and excluding the intermetallic interaction, the coordination around $\operatorname{Ir}(1)$ is severely distorted square pyramidal, with $\mathrm{S}(4), \mathrm{N}(1)$ and the cyclooctadiene molecule on the base, and S(1) at the apex. The geometric environment of $\operatorname{Ir}(2)$ can be better described as a distorted trigonal bipyramid, with $S(2), S(4)$ and one olefinic bond of a cod molecule in the equatorial plane, while $\mathrm{N}(2)$ and the other double bond of the cod ligand are at the apices. The complexity of these two coordination environments seems 
arise from the rigidity of the two bridging ligands and from the distinct coordination modes rather than for electronic reasons. From an electronic point of view, the $\operatorname{Ir}(1)$ and $\operatorname{Ir}(2)$ atoms are bonded to five 2-electron donors besides the metal-metal bond, a usual situation for a $\mathrm{d}^{7}$ $\mathrm{d}^{7}$ system following the 18-e rule with an intermetallic bond.

The Ir-S distances are in the range 2.327-2.442(3) $\AA$, being the shorter and the larger those of the sulfur atoms with a $\kappa^{1}$ coordination. The four remaining Ir-S bond lengths, corresponding to bridging sulfurs, are in the range 2.336-2.406(2) $\AA$. The quite long $\operatorname{Ir}(1)-\mathrm{S}(1)$ distance may be due to the geometric restrains imposed by the chelate coordination. The C-S distances are longer for the bridging sulfurs $(1.774$ and $1.781(10) \AA)$ than for the $\kappa^{1}$ sulfur atoms $(1.739$ and $1.745(10) \AA$ ), according to a smaller bond order for the former. ${ }^{14}$

\section{General and theoretical considerations}

The compounds $\left.\left[\mathrm{M}_{4}\left(\boldsymbol{\mu}-\mathrm{PyS}_{2}\right)_{2} \text { (diolefin }\right)_{4}\right]^{+}\left(\mathbf{1}^{+}-\mathbf{3}^{+}\right)$, resulting from the one-electron oxidation of the 64-electron tetranuclear precursors 1-3, are 63-electron mixed-valence paramagnetic complexes. The chemical reversibility associated to the redox change strongly suggest that the tetranuclear framework remains unchanged after the oxidation process, although structural modifications are expected to affect mainly to the metal-metal separations and slightly to the metal-ligand separations, as observed for related trinuclear complexes. ${ }^{12}$ Indeed, a shortening of the metal-metal distances upon oxidation has been frequently observed in related dinuclear complexes where the HOMO is a metal-based orbital antibonding in character. ${ }^{10,22}$

We have carried out an extended Hückel molecular orbital (EHMO) calculation ${ }^{23}$ based on the molecular parameters obtained from the X-ray data of complex $\left[\mathrm{Rh}_{4}\left(\mu-\mathrm{PyS}_{2}\right)_{2}(\operatorname{cod})_{4}\right]$ (1) under $\mathrm{C}_{2}$ symmetry. An interesting result from these calculations was to find a net overlap between one external rhodium atom and its inner neighbor (overlap population $0.013 \mathrm{e}^{-}$), while there is a slightly antibonding character between the two inner rhodium atoms (overlap population $\left.-0.006 \mathrm{e}^{-}\right)$. This bonding scheme is consistent with the long distance between the inner rhodium atoms (3.921 $)$ ), and the short separations between an inner and the nearest external rhodium atom (3.143 $\AA$ ) observed in the molecular structure of complex 1 (Figure 1). The HOMO orbital in the tetranuclear complexes is a metal-based orbital that results from the 
combination of $\mathrm{d}_{\mathrm{z}}{ }^{2}$ orbitals of the four rhodium atoms. Depopulation of the HOMO causes a substantial rise in the $\mathrm{Rh}$....Rh overlap population, which affects mainly to the already interacting metals in the non oxidized species, and indicates that the HOMO of the $\left[\mathrm{M}_{4}\right]$ and $\left[\mathrm{M}_{4}\right]^{+}$species are antibonding in character.

If the $\mathrm{C}_{2}$ symmetry and the molecular geometry were maintained for the $\left[\mathrm{M}_{4}\right]^{+}$and $\left[\mathrm{M}_{4}\right]^{2+}$ species, the calculated overlap populations between one external rhodium atom and its inner neighbor would be 0.033 and 0.053 , respectively, while almost no interaction would be found between the inner rhodium atoms (overlap populations $0.000 \mathrm{e}^{-}$and $0.005 \mathrm{e}^{-}$, respectively). In addition, the calculated charges for the external and internal rhodium atoms (0.118 and 0.281 for $\left[\mathrm{M}_{4}\right], 0.249$ and 0.521 for $\left[\mathrm{M}_{4}\right]^{+}$, and 0.380 and 0.761 for $\left[\mathrm{M}_{4}\right]^{2+}$, respectively) indicate that the depopulation of the HOMO upon oxidation affects strongly to the two internal rhodium atoms. These results indicate the general tendency of the bonding of the metal framework upon oxidation, although the model even for the $\left[\mathrm{M}_{4}\right]^{+}$compounds cannot be validated, since we have not a structural determination for the oxidized species.

The hyperfine coupling observed in the EPR spectrum of the rhodium cation $\mathbf{1 a}^{+}$clearly stablishes that the odd-electron spin density is delocalized between two equivalent metals to give a triplet. In other words, the two internal metals in the structure of $\mathbf{1}$ share the unpaired electron. Moreover, if there were an interaction of this electron with the two external metals it would be very weak, since it would only produce the broadening of the lines of the triplet. Therefore, the formation of a bond of order $1 / 2$ between the internal metals occurs after the first oxidation, which should lead to an aproximation of these two metals relative to $\mathbf{1}$, and to a larger separation and weakening of their interactions with the external metals. These structural changes made that the calculations of the overlap populations for the HOMO in the $\left[\mathrm{M}_{4}\right]^{+}$species are not reliable.

The delocalization of the odd-electron spin over two metals in the $\left[\mathrm{M}_{4}\right]^{+}$complexes can be deduced from their EPR spectra through the mean $g$-value. The EPR data from several mono-, di- and trinuclear paramagnetic rhodium complexes $\left(\left[\mathrm{Rh}_{n}\right], \mathrm{n}=1,2,3\right)$ indicate a good correlation between the mean $g$-value and the number of interacting metal atoms, in such a way that the shift of the mean $g$-factor from that of the free electron $g$-value $\left(g_{e}=\right.$ 
2.0023) becomes smaller as the number of the rhodium atoms increases. Paramagnetic square-planar mononuclear rhodium(II) complexes $(\mathrm{n}=1)$, such as $\left[\mathrm{Rh}_{(}\left(\mathrm{C}_{6} \mathrm{Cl}_{5}\right)_{2}\left(\mathrm{PR}_{3}\right)_{2}\right],{ }^{24}$ $\left[\mathrm{Rh}\left(\mathrm{C}_{6} \mathrm{Cl}_{5}\right)_{2}(\mathrm{cod})\right],{ }^{24}$ and $\left[\mathrm{Rh}\left(2,4,6-\mathrm{Pr}_{3} \mathrm{C}_{6} \mathrm{H}_{2}\right)_{2}(\text { tht })_{2}\right]^{25}$ (tht = tetrahydrothiophene) show typical $g$-values in the range 2.46-2.32. The mean $g$-values in mixed-valence face-to-face dinuclear rhodium complexes $(n=2)$ with ancillary $\pi$-acceptor carbonyl ligands, such as $\left[\mathrm{Rh}_{2}(\mu-\mathrm{PhNC}(\mathrm{Me}) \mathrm{NPh})_{2}(\mathrm{CO})_{2}\left(\mathrm{PPh}_{3}\right)_{2}\right]$ and $\left[\mathrm{Rh}_{2}(\mu-\mathrm{RNNNR})_{2}(\mathrm{CO})_{2}\left(\mathrm{PPh}_{3}\right)_{2}\right](\mathrm{R}=p$-tolyl $)$, show mean $g$-values of 2.119 and 2.118 respectively. ${ }^{26}$ Slightly higher values are found for related dinuclear complexes with diolefins as auxiliary ligands such as $\left[\operatorname{Rh}_{2}(\mu-m h p)_{2}(\operatorname{cod})_{2}\right]$, $\left[\mathrm{Rh}_{2}(\mu-\mathrm{chp})_{2}(\mathrm{nbd})_{2}\right]$ and $\left[\mathrm{Rh}_{2}(\mu-\mathrm{mhp})_{2}(\mathrm{nbd})_{2}\right](\mathrm{mhp}=6$-methyl-2-hydroxypyridinate, $\mathrm{chp}=$ 6-chloro-2-hydroxypyridinate, $\mathrm{nbd}=2,5$-norbornadiene) with mean g-values of 2.218, 2.181 and 2.178 in frozen solutions, respectively. ${ }^{10}$ The diolefin complexes $\left[\operatorname{Rh}_{2}(\mu-1,8-\right.$ $\left.(\mathrm{NH})_{2} \mathrm{C}_{10} \mathrm{H}_{6}\right)$ (diolefin) 2 ] (diolefin= cod, nbd, tfbb) also exhibit mean $g$-values ranging 2.1492.141 in $\mathrm{CH}_{2} \mathrm{Cl}_{2}$ at room temperature. ${ }^{27}$ Interestingly, the linear trinuclear rhodium complexes $\quad(\mathrm{n} \quad=\quad 3) \quad\left[\mathrm{Rh}_{3}\left(\mu_{3} \text {-Onapy }\right)(\mathrm{CO})_{4}\left(\mathrm{PPh}_{3}\right)_{2}\right]^{2+}$ and $\left[\mathrm{Rh}_{3}\left(\mu_{3^{-}}\right.\right.$ $\mathrm{OMe}_{2}$ napy $\left.)(\mathrm{CO})_{4}\left(\mathrm{PPh}_{3}\right)_{2}\right]^{2+}\left(\mathrm{Onapy}=1,8\right.$-naphthyridine-2-onate, $\mathrm{OMe}_{2}$ napy = 5,7-dimethyl1,8-naphthyridine-2-onate) show smaller mean $g$-factors of 2.091 and 2.085 , respectively, 28 while the mean $g$-values for the diolefin trinuclear complexes $\left[\mathrm{Rh}_{3}\left(\mu_{3} \text {-Onapy }(\mathrm{CO})_{2}(\mathrm{cod})_{2}\right]^{2+}\right.$ and $\mathrm{Rh}_{3}\left(\mu_{3}-\mathrm{OMe}_{2}\right.$ napy $\left.)(\mathrm{CO})_{2}(\mathrm{cod})_{2}\right]^{2+}, 2.122$ and 2.119 respectively, are slightly larger. ${ }^{28}$ Although there is less data concerning the mean $g$-factor in iridium complexes, the mononuclear complex $\left[\operatorname{Ir}\left(\mathrm{C}_{6} \mathrm{Cl}_{5}\right)_{2}(\mathrm{cod})\right]$ shows a mean $g$-value of $2.540,{ }^{29}$ whereas the values found for the dinuclear complexes $\left[\operatorname{Ir}_{2}\left(\mu-2,5-\mathrm{Me}_{2} \mathrm{pz}\right)(\operatorname{cod})\right]\left[\mathrm{BF}_{4}\right]^{30}$ and $\left[\operatorname{Ir}_{2}(\mu \text {-anp)(cod) }]^{+}\right.$ $(\text { anp }=2 \text {-anilinopyridinato })^{31}$ are 2.34 and 2.27 respectively.

Taking into account this figures, the mean $g$-value for the complexes $\left[\operatorname{Rh}_{4}(\mu\right.$ $\left.\left.\mathrm{PyS}_{2}\right)_{2}(\mathrm{cod})_{4}\right] \mathrm{PF}_{6}\left(\mathbf{1 a}^{+}\right)(g \approx 2.16),\left[\mathrm{Rh}_{4}\left(\mu-\mathrm{PyS}_{2}\right)_{2}(\mathrm{tfbb})_{4}\right] \mathrm{BF}_{4}\left(\mathbf{2 b}^{+}\right)(g \approx 2.11)$ and $\left[\mathrm{Ir}_{4}(\mu-\right.$ $\left.\left.\mathrm{PyS}_{2}\right)_{2}(\mathrm{cod})_{4}\right]\left[\mathrm{BF}_{4}\right]\left(3^{+}\right)(g \approx 2.24)$ suggests that the unpaired electron is mainly shared by two rhodium or two iridium atoms; the smaller mean $g$-value found for complex $\left[\mathrm{Rh}_{4}(\mu\right.$ $\left.\left.\mathrm{PyS}_{2}\right)_{2}(\mathrm{tfbb})_{4}\right] \mathrm{PF}_{6}\left(\mathbf{2 b}^{+}\right)(g \approx 2.11)$ could be due to the $\pi$-acceptor properties of the tfbb ligands. Therefore, we can assume that the odd-electron spin density in the monocations 
$\left[\mathrm{M}_{4}\right]^{+}$is distributed between the two internal metal atoms, as found for $\mathbf{1 a}^{+}$, and these two metals would have $\mathrm{d}^{7}-\mathrm{d}^{8}$ configurations with delocalized valence.

A main change occurs after the abstraction of an electron from the $\left[\mathrm{M}_{4}\right]^{+}$species. Although the formation of the $\left[\mathrm{M}_{4}\right]^{2+}$ species were detected by cyclic voltammetry, they decompose in short time. The fate of the dioxidized species $\left[\mathrm{M}_{4}\right]^{2+}$ for rhodium is unknown, but the iridium compounds evolve to the trinuclear complexes $\left.\left[\operatorname{Ir}_{3}\left(\mu-\mathrm{PyS}_{2}\right)_{2} \text { (diolefin }\right)_{3}\right]^{+}(\mathbf{5}-$ 6), which were also detected by the $\mathrm{CV}$ experiment. A comparison of the molecular structures of $\mathbf{5 b}$ and $\mathbf{3}$ evidences that in going from $\mathbf{3}$ to $\mathbf{5}$ the metal fragment extruded would be located at an external position of the tetranuclear framework, and the metal-metal bond is formed between the inner metal centres in $\mathbf{3}$. Scheme 2 shows a reliable proposal for this process. While the first oxidation of the $\left[\mathrm{M}_{4}\right]$ species produces the mixed-valence species $\left[\mathrm{M}_{4}\right]^{+}$with the valence delocalized within the two internal metals (Ir2-Ir3), the second oxidation would lead to a two-electron mixed-valence $\left[\mathrm{M}_{4}\right]^{2+}$ species. The second electron would be expected to come from the previous oxidized metals, the inner metals (Ir 2, or Ir 2 and $\operatorname{Ir} 3$ ), for which the EHMO calculation indicates to have a high positive charge. This would lead to either a compound with $d^{8}-d^{6}-d^{8}-d^{8}$ metal centers that should undergo a significant change in the coordination environment of the $\mathrm{d}^{6}$ metal, as postulated by Bosnich and Nocera, ${ }^{32}$ or to the diradical with $d^{8}-d^{7}-d^{7}-d^{8}$ metals and a high configurational strain. In the first case, the oxidized metal would interact with a sulfur atom of the bridging ligand to fulfil the coordination requirements and with the other inner Ir atom (Ir 3) to produce an internal comproportionation to a $\mathrm{d}^{7}-\mathrm{d}^{7}$ species through a metal-metal bond. Such localized central metal-metal bond should be formed between the internal iridium atoms $(\operatorname{Ir} 2, \operatorname{Ir} 3)$ in the diradical species. In both cases, the interactions of the internal iridium atoms (Ir 2, Ir 3) with two neighbor sulfur atoms of the bridging ligands weaken the Ir-S links with an external $\mathrm{d}^{8}$ iridium metal (Ir 4), which is finally extruded from the tetranuclear framework.

\section{Concluding Remarks}

The rhodium and iridium tetranuclear complexes $\left[\mathrm{M}_{4}\right]$ are redox-active species that undergo two stepwise one-electron oxidation processes. Although both $\left[\mathrm{M}_{4}\right]^{+}$and $\left[\mathrm{M}_{4}\right]^{2+}$ species have been electrochemically detected, only the mono-oxidized complexes are cleanly 
obtained by chemical oxidation of the corresponding tetranuclear complexes using mild oneelectron oxidants. The mono-oxidized $\left[\mathrm{M}_{4}\right]^{+}$species are mixed-valence paramagnetic complexes likely exhibiting a tetranuclear framework similar to that of the neutral precursors but with uneven intermetallic separations. The two-electron oxidation of the [ $\left.\operatorname{Ir}_{4}\right]$ complexes produces the degradation of the tetranuclear structure and the formation of diamagnetic triiridium cations $\left[\operatorname{Ir}_{3}\right]^{+}$. These unexpected $d^{7}-d^{7}-d^{8}$ trinuclear complexes possess a localized iridium-iridium bond and exhibit unusual coordination modes for both 2,6-pyridinedithiolate bridging ligands. The structural reorganization leading to the trinuclear complexes is probably a consequence of the instability of the intermediary di-oxidized $\left[\mathrm{Ir}_{4}\right]^{2+}$ species.

\section{Experimental Section}

General Methods All manipulations were performed under a dry nitrogen atmosphere using Schlenk-tube techniques. Solvents were dried by standard methods and distilled under nitrogen immediately prior to use. The tetranuclear complexes $\left[\mathrm{Rh}_{4}\left(\mu-\mathrm{PyS}_{2}\right)_{2}(\mathrm{cod})_{4}\right](\mathbf{1})$, $\left[\mathrm{Rh}_{4}\left(\mu-\mathrm{PyS}_{2}\right)_{2}(\mathrm{tfbb})_{4}\right]$ (2) and $\left[\operatorname{Ir}_{4}\left(\mu-\mathrm{PyS}_{2}\right)_{2}(\operatorname{cod})_{4}\right]$ (3) were prepared as described previously. ${ }^{14}$ Standard literature procedures were used to prepare $\left[\mathrm{Cp}_{2} \mathrm{Fe}\right] \mathrm{PF}_{6}{ }^{33},[\operatorname{Ir}(\mu$ $\mathrm{OMe})(\mathrm{tfbb})]_{2}{ }^{34}$ and $\mathrm{N}\left(p-\mathrm{BrC}_{6} \mathrm{H}_{4}\right)_{3}{ }^{35}$. The silver salts and $\mathrm{NOPF}_{6}$ were purchased from Fluka Chem. and Aldrich, respectively, and used as received.

Physical Measurements. IR spectra were recorded on a Nicolet 550 spectrometer using Nujol mulls between polyethylene sheets. Elemental C, $\mathrm{H}$ and $\mathrm{N}$ analysis were performed in a 240-C Perkin-Elmer microanalyzer. Conductivities were measured in ca. 5.10-4 $\mathrm{M}$ acetone solutions using a Philips PW 9501/01 conductimeter. Mass spectra were recorded in a VG Autospec double-focusing mass spectrometer operating in the $\mathrm{FAB}^{+}$mode. Ions were produced with the standard $\mathrm{Cs}^{+}$gun at $c a .30 \mathrm{KV}$; 3-nitrobenzyl alcohol (NBA) was used as matrix. ${ }^{1} \mathrm{H}$ NMR spectra were recorded on Varian UNITY 300 spectrometer operating at 299.95 MHz. Chemical shifts are referenced to $\mathrm{SiMe}_{4}$. EPR spectra were measured in a Bruker ESP380E spectrometer working either in X-band $(\approx 9.5 \mathrm{GHz})$ or Q-band $(\approx 34 \mathrm{GHz})$. Powdered polycrystalline samples or solutions of the complexes in dichloromethane:THF 2:1 were introduced in standard EPR quartz tubes and the spectra were run at room temperature 
and at the liquid nitrogen temperature. The magnetic field was measured with a Bruker ER035M NMR gaussmeter and a 5350B HP frequency counter was used for determining the microwave frequency. Cyclic voltammetric experiments were performed with an EG\&G PARC Model 273 potentiostat/galvanostat. A three-electrode glass cell consisting of a platinum-disk working electrode, a platinum-wire auxiliary electrode and a standard calomel reference electrode (SCE) was used. Linear voltamperometry was performed using a rotating platinum electrode (RDE) as the working electrode. Tetra-nbutylammoniumhexafluorophosphate (TBAH) was employed as supporting electrolyte. Electrochemical experiments were carried out under nitrogen in ca. $5 \cdot 10^{-4} \mathrm{M}$ dichloromethane solutions of the complexes and $0.1 \mathrm{M}$ in TBAH. The $\left[\mathrm{Fe}\left(\mathrm{C}_{5} \mathrm{H}_{5}\right)_{2}\right]^{+/}\left[\mathrm{Fe}\left(\mathrm{C}_{5} \mathrm{H}_{5}\right)_{2}\right]$ couple is observed at $+0.47 \mathrm{~V}$ under these experimental conditions.

Preparation of the complexes. $\left[\operatorname{Ir}_{4}\left(\mu-P_{y} S_{2}\right)_{2}(t f b b)_{4}\right](4)$. To a yellow suspension of $[\operatorname{Ir}(\mu-\mathrm{OMe})(\mathrm{tfbb})]_{2}(0.227 \mathrm{~g}, 0.253 \mathrm{mmol})$ in dichloromethane $(10 \mathrm{~mL})$ solid $\mathrm{Py}(\mathrm{SH})_{2}(0.036$ $\mathrm{g}, 0.253 \mathrm{mmol}$ ) was added. A dark green solution was immediately formed and a green solid began to crystallize out after stirring for 15 minutes. Methanol $(10 \mathrm{~mL})$ was added to complete the crystallization, and the microcrystalline solid was collected by filtration, washed with methanol and dried under vacuum. Yield: $0.174 \mathrm{~g}$ (70\%). Anal. Calcd for $\mathrm{C}_{50} \mathrm{H}_{30} \mathrm{~F}_{16} \mathrm{Ir}_{4} \mathrm{~N}_{2} \mathrm{~S}_{4}: \mathrm{C}, 30.70 ; \mathrm{H}, 1.54 ; \mathrm{N}, 1.43$. Found: C, 30.50; H, 1.49; N, 1.43. MS (FAB ${ }^{+}$, $\left.\mathrm{CH}_{2} \mathrm{Cl}_{2}, \mathrm{~m} / \mathrm{z}\right): 1956\left(\left[\operatorname{Ir}_{4}\left(\mu-\mathrm{PyS}_{2}\right)_{2}(\mathrm{tfbb})_{4}\right]^{+}, 25 \%\right), 1537\left(\left[\operatorname{Ir}_{3}\left(\mu-\mathrm{PyS}_{2}\right)_{2}(\mathrm{tfbb})_{3}\right]^{+}, 30 \%\right) .{ }^{1} \mathrm{H}$ NMR $\left(\mathrm{CDCl}_{3}, 213 \mathrm{~K}\right) \delta: 7.89\left(\mathrm{dd}, 2 \mathrm{H}, \mathrm{J}_{\mathrm{H}-\mathrm{H}}=7.1 \mathrm{~Hz}, \mathrm{~J}_{\mathrm{H}-\mathrm{H}}=1.6 \mathrm{~Hz}\right), 6.85-6.79$ (set of $\left.\mathrm{m}, 4 \mathrm{H}\right)$ (PyS 2 ligands), $5.77(\mathrm{~m}, 2 \mathrm{H}, \mathrm{CH}), 5.64(\mathrm{~m}, 2 \mathrm{H}, \mathrm{CH}), 5.56(\mathrm{~m}, 4 \mathrm{H}, \mathrm{CH}), 4.40(\mathrm{~m}, 2 \mathrm{H},=\mathrm{CH})$, $3.80(\mathrm{~m}, 2 \mathrm{H},=\mathrm{CH}), 3.53(\mathrm{~m}, 2 \mathrm{H},=\mathrm{CH}), 3.41(\mathrm{~m}, 2 \mathrm{H},=\mathrm{CH}), 3.30(\mathrm{~m}, 2 \mathrm{H},=\mathrm{CH}), 3.20(\mathrm{~m}, 2 \mathrm{H}$, $=\mathrm{CH}), 2.80(\mathrm{~m}, 2 \mathrm{H},=\mathrm{CH}), 2.19(\mathrm{~m}, 2 \mathrm{H},=\mathrm{CH})$ (tfbb ligands).

$\left[\mathbf{R h}_{\mathbf{4}}\left(\boldsymbol{\mu}-\mathbf{P y S}_{\mathbf{2}}\right)_{\mathbf{2}}(\mathbf{c o d})_{4}\right] \mathbf{P F}_{6}\left(\mathbf{1 a}^{+}\right)$. Method A. Solid $\left[\mathrm{Cp}_{2} \mathrm{Fe}_{\mathrm{PF}}(0.031 \mathrm{~g}, 0.095 \mathrm{mmol})\right.$ was added to a solution of $\left[\mathrm{Rh}_{4}\left(\mu-\mathrm{PyS}_{2}\right)_{2}(\operatorname{cod})_{4}\right]$ (1) $(0.107 \mathrm{~g}, 0.095 \mathrm{mmol})$ in dichloromethane $(15 \mathrm{~mL})$ and the mixture was stirred for one hour at room temperature. The resulting dark brown solution was concentrated under vacuum to $c a .1 \mathrm{~mL}$. Slow addition of diethyl ether $(5 \mathrm{~mL})$ gave $\mathbf{1 a}^{+}$as a brown microcrystalline solid, which was filtered off,

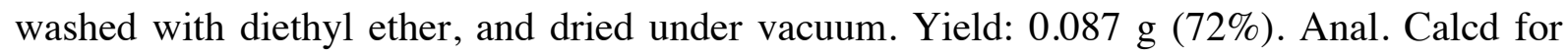


$\mathrm{C}_{42} \mathrm{H}_{54} \mathrm{~F}_{6} \mathrm{~N}_{2} \mathrm{Rh}_{4} \mathrm{~S}_{4}: \mathrm{C}, 39.67 ; \mathrm{H}, 4.28 ; \mathrm{N}, 2.20$. Found: C, 39.74; H, 4.30; N, 2.15. MS $\left(\mathrm{FAB}^{+}, \mathrm{CH}_{2} \mathrm{Cl}_{2}, \mathrm{~m} / \mathrm{z}\right): 1126\left(\left[\mathrm{Rh}_{4}\left(\mu-\mathrm{PyS}_{2}\right)_{2}(\operatorname{cod})_{4}\right]^{+}, 100 \%\right), 1019\left(\left[\mathrm{Rh}_{4}\left(\mu-\mathrm{PyS}_{2}\right)_{2}(\operatorname{cod})_{3}\right]^{+}\right.$, $\left.15 \%), 906\left(\mathrm{Rh}_{4}\left(\mu-\mathrm{PyS}_{2}\right)_{2}(\mathrm{cod})_{2}\right]^{+}, 17 \%\right) . \Lambda_{\mathrm{M}}\left(\Omega^{-1} \mathrm{~cm}^{2} \mathrm{~mol}^{-1}\right): 130$ (acetone, $\left.5.0 \cdot 10^{-4} \mathrm{M}\right)$.

Method B. A filtered dark blue solution of $\left[\mathrm{N}\left(\mathrm{C}_{6} \mathrm{H}_{4} \mathrm{Br}-4\right)_{3}\right] \mathrm{PF}_{6}$, generated in situ by reaction of $\mathrm{N}\left(\mathrm{C}_{6} \mathrm{H}_{4} \mathrm{Br}-4\right)_{3}(0.043 \mathrm{~g}, 0.089 \mathrm{mmol})$ with solid $\mathrm{NOPF}_{6}(0.031 \mathrm{~g}, 0.177 \mathrm{mmol})$ in dichloromethane $(12 \mathrm{~mL})$ for 10 minutes under argon, was added to a solution of $\left[\mathrm{Rh}_{4}(\mu\right.$ $\left.\left.\mathrm{PyS}_{2}\right)_{2}(\mathrm{cod})_{4}\right](0.100 \mathrm{~g}, 0.089 \mathrm{mmol})$ in dichloromethane $(15 \mathrm{~mL})$ to give a dark brown solution. Work-up as described above gave $0.071 \mathrm{~g}$ of $1 \mathbf{a}^{+}$(Yield: $63 \%$ ).

$\left[\mathrm{Rh}_{4}\left(\mu-\mathrm{PyS}_{2}\right)_{2}(\operatorname{cod})_{4}\right] \mathrm{X} .\left[\mathrm{X}=\mathrm{PF}_{6}\left(1 \mathrm{a}^{+}\right), \mathrm{BF}_{4}\left(\mathbf{1 b}^{+}\right), \mathrm{ClO}_{4}\left(1 \mathrm{c}^{+}\right)\right]$. In a typical procedure solid $\mathrm{Cp}_{2} \mathrm{Fe}(0.100 \mathrm{mmol})$ was reacted with the appropriate silver salt $\mathrm{AgX}(0.090 \mathrm{mmol})(\mathrm{X}=$ $\mathrm{PF}_{6}, \mathrm{BF}_{4}$ or $\left.\mathrm{ClO}_{4}\right)$ in acetone $(10 \mathrm{~mL})$ with exclusion of light. The blue mixture was stirred for 30 minutes and then filtered through celite over a solution of $\left[\mathrm{Rh}_{4}\left(\mu-\mathrm{PyS}_{2}\right)_{2}(\operatorname{cod})_{4}\right](0.100$ $\mathrm{g}, 0.089 \mathrm{mmol})$ in dichloromethane $(15 \mathrm{~mL})$. Work-up as above gave the complexes as dark brown microcrystalline solids. $\left(\mathbf{1 a}^{+}\right)$: Yield: $75 \%$. $\left(\mathbf{1 b}^{+}\right)$: Yield: $70 \%$. Anal. Calcd for $\mathrm{C}_{42} \mathrm{H}_{54} \mathrm{BF}_{4} \mathrm{~N}_{2} \mathrm{Rh}_{4} \mathrm{~S}_{4}: \mathrm{C}, 41.56 ; \mathrm{H}, 4.48 ; \mathrm{N}, 2.31$. Found: $\mathrm{C}, 41.41 ; \mathrm{H}, 4.00 ; \mathrm{N}, 2.28 . \Lambda_{\mathrm{M}}\left(\Omega^{-}\right.$ $\left.{ }^{1} \mathrm{~cm}^{2} \mathrm{~mol}^{-1}\right)$ : 118 (acetone, 5.6.10-4 M). $\left(\mathbf{1 c}^{+}\right)$: Yield: 75\%. Anal. Calcd for $\mathrm{C}_{42} \mathrm{H}_{54} \mathrm{ClN}_{2} \mathrm{O}_{4} \mathrm{Rh}_{4} \mathrm{~S}_{4}: \mathrm{C}, 41.14 ; \mathrm{H}, 4.44 ; \mathrm{N}, 2.28$. Found: $\mathrm{C}, 41.10 ; \mathrm{H}, 4.20 ; \mathrm{N}, 2.25 . \Lambda_{\mathrm{M}}\left(\Omega^{-}\right.$ ${ }^{1} \mathrm{~cm}^{2} \mathrm{~mol}^{-1}$ ): 106 (acetone, $5.01 \cdot 10^{-4} \mathrm{M}$ ).

$\left[\mathbf{R h}_{\mathbf{4}}\left(\boldsymbol{\mu}-\mathbf{P y S}_{\mathbf{2}}\right)_{\mathbf{2}}(\mathbf{t f b b})_{4}\right] \mathbf{P F}_{6}\left(\mathbf{2 a}^{+}\right) .\left[\mathrm{Cp}_{2} \mathrm{Fe}\right] \mathrm{PF}_{6}(0.015 \mathrm{~g}, 0.047 \mathrm{mmol})$ was added to a solution of $\left[\mathrm{Rh}_{4}\left(\mu-\mathrm{PyS}_{2}\right)_{2}(\mathrm{tfbb})_{4}\right](2)(0.075 \mathrm{~g}, 0.047 \mathrm{mmol})$ in dichloromethane $(15 \mathrm{~mL})$ to give a green-red dichroic solution, which was stirred for $30 \mathrm{~min}$. On concentration, a dark green solid crystallized out. Slow addition of diethyl ether $(10 \mathrm{~mL})$ gave $\mathbf{2 \mathbf { a } ^ { + }}$ as a dark green microcrystalline solid which was filtered off, washed with diethyl ether and dried under vacuum. Yield: $0.063 \mathrm{~g}(80 \%)$. Anal. Calcd for $\mathrm{C}_{58} \mathrm{H}_{30} \mathrm{~F}_{22} \mathrm{~N}_{2} \mathrm{Rh}_{4} \mathrm{~S}_{4}$ : C, 39.95; H, 1.73; N, 1.60. Found: $\mathrm{C}, 39.85 ; \mathrm{H}, 1.52 ; \mathrm{N}, 1.63$. $\mathrm{MS}\left(\mathrm{FAB}^{+}, \mathrm{CH}_{2} \mathrm{Cl}_{2}, \mathrm{~m} / \mathrm{z}\right): 1598\left(\left[\mathrm{Rh}_{4}(\mu-\right.\right.$ $\left.\left.\left.\mathrm{PyS}_{2}\right)_{2}(\mathrm{tfbb})_{4}\right]^{+}, 100 \%\right), 1372\left(\left[\mathrm{Rh}_{4}\left(\mu-\mathrm{PyS}_{2}\right)_{2}(\mathrm{tfbb})_{3}\right]^{+}, 4 \%\right) . \Lambda_{\mathrm{M}}\left(\Omega^{-1} \mathrm{~cm}^{2} \mathrm{~mol}^{-1}\right): 106$ (acetone, $4.81 \cdot 10^{-4} \mathrm{M}$ ).

$\left[\mathrm{Rh}_{4}\left(\mu-\mathrm{PyS}_{2}\right)_{2}(\mathrm{tfbb})_{4}\right] \mathrm{X}\left[\mathrm{X}=\mathrm{PF}_{6}\left(2 \mathrm{a}^{+}\right), \mathrm{BF}_{4}\left(\mathbf{2 b}^{+}\right), \mathrm{ClO}_{4}\left(2 \mathrm{c}^{+}\right)\right]$. Complexes $\mathbf{2}^{+}$were also prepared using freshly made solutions of the oxidant $\left[\mathrm{Cp}_{2} \mathrm{Fe}\right] \mathrm{X}\left(\mathrm{X}=\mathrm{PF}_{6}, \mathrm{BF}_{4}\right.$ and $\left.\mathrm{ClO}_{4}\right)$ 
following the procedure described above. The complexes were obtained as dark green microcrystalline solids in high yield $\left(0.063 \mathrm{mmol}\right.$ scale): $\left(\mathbf{2 a}^{+}\right)$: Yield: $75 \%$. $\left(\mathbf{2 b}^{+}\right)$: Yield: 78\%. Anal. Calcd for $\mathrm{C}_{58} \mathrm{H}_{30} \mathrm{BF}_{20} \mathrm{~N}_{2} \mathrm{Rh}_{4} \mathrm{~S}_{4}: \mathrm{C}, 41.33 ; \mathrm{H}, 1.79 ; \mathrm{N}, 1.66$. Found: $\mathrm{C}, 41.28 ; \mathrm{H}$, 1.62; $\mathrm{N}, 1.63 . \Lambda_{\mathrm{M}}\left(\Omega^{-1} \mathrm{~cm}^{2} \mathrm{~mol}^{-1}\right): 121$ (acetone, 4.69.10-4 M). $\left(2 \mathrm{c}^{+}\right)$: Yield: $78 \%$. Anal. Calcd for $\mathrm{C}_{58} \mathrm{H}_{30} \mathrm{ClF}_{16} \mathrm{~N}_{2} \mathrm{O}_{4} \mathrm{Rh}_{4} \mathrm{~S}_{4}: \mathrm{C}, 41.04 ; \mathrm{H}, 1.78 ; \mathrm{N}, 1.65$. Found: $\mathrm{C}, 40.89 ; \mathrm{H}, 1.63 ; \mathrm{N}, 1.62$. $\Lambda_{\mathrm{M}}\left(\Omega^{-1} \mathrm{~cm}^{2} \mathrm{~mol}^{-1}\right): 114$ (acetone, $\left.4.89 \cdot 10^{-4} \mathrm{M}\right)$.

$\left[\operatorname{Ir}_{\mathbf{4}}\left(\boldsymbol{\mu}-\mathbf{P y S}_{2}\right)_{\mathbf{2}}(\mathbf{c o d})_{\mathbf{4}}\right]\left[\mathbf{B F}_{\mathbf{4}}\right]\left(\mathbf{3}^{+}\right)$. A solution of $\mathrm{AgBF}_{4}(0.011 \mathrm{~g}, 0.057 \mathrm{mmol})$ in acetone $(5 \mathrm{~mL})$ was added over a solution of $\left[\operatorname{Ir}_{4}\left(\mu-\mathrm{PyS}_{2}\right)_{2}(\mathrm{cod})_{4}\right](3)(0.084 \mathrm{~g}, 0.057 \mathrm{mmol})$ in dichloromethane $(10 \mathrm{~mL})$ with exclusion of light. The dark green mixture formed was stirred for one hour and then filtered through celite under nitrogen to remove metallic silver. Concentration of the filtrate under reduced pressure to ca. $1 \mathrm{~mL}$, and slow addition of diethyl ether $(5 \mathrm{~mL})$ gave $\mathbf{3}^{+}$as a dark green microcrystalline solid. The solid, which was isolated in the Schlenk-tube, was washed with diethyl ether $(2 \times 5 \mathrm{~mL})$ and dried under vacuum. Yield: $0.058 \mathrm{~g}(65 \%)$. Anal. Calcd for $\mathrm{C}_{42} \mathrm{H}_{54} \mathrm{BF}_{4} \mathrm{Ir}_{4} \mathrm{~N}_{2} \mathrm{~S}_{4}: \mathrm{C}, 32.11 ; \mathrm{H}, 3.47 ; \mathrm{N}, 1.78$. Found: C, 32.21; H, 3.49; N, 1.72. MS (FAB $\left.{ }^{+}, \mathrm{CH}_{2} \mathrm{Cl}_{2}, \mathrm{~m} / \mathrm{z}\right): 1484\left(\left[\operatorname{Ir}_{4}\left(\mu-\mathrm{PyS}_{2}\right)_{2}(\operatorname{cod})_{4}\right]^{+}, 100 \%\right), 1373$ $\left(\left[\operatorname{Ir}_{4}\left(\mu-\mathrm{PyS}_{2}\right)_{2}(\operatorname{cod})_{3}\right]^{+}, 7 \%\right), 1183\left(\left[\operatorname{Ir}_{3}\left(\mu-\mathrm{PyS}_{2}\right)_{2}(\operatorname{cod})_{3}{ }^{+}, 67 \%\right) . \Lambda_{\mathrm{M}}\left(\Omega^{-1} \mathrm{~cm}^{2} \mathrm{~mol}^{-1}\right): 130\right.$ (acetone, $5.02 \cdot 10^{-4} \mathrm{M}$ ).

$\left[\operatorname{Ir}_{3}\left(\mu-\mathbf{P y S}_{2}\right)_{2}(\operatorname{cod})_{3}\right] \mathbf{X}\left[\mathbf{X}=\mathbf{P F}_{6}(\mathbf{5 a}), \mathbf{X}=\mathbf{B F}_{4}(\mathbf{5 b})\right]$. Method A. A filtered dark blue solution of $\left[\mathrm{N}\left(\mathrm{C}_{6} \mathrm{H}_{4} \mathrm{Br}-4\right)_{3}\right] \mathrm{PF}_{6}(0.101 \mathrm{mmol})$ in dichloromethane $(12 \mathrm{~mL})$ prepared as described above, was added to a solution of $\left[\operatorname{Ir}_{4}\left(\mu-\mathrm{PyS}_{2}\right)_{2}(\operatorname{cod})_{4}\right](0.075 \mathrm{~g}, 0.051 \mathrm{mmol})$ in dichloromethane $(10 \mathrm{~mL})$ to give a green solution, which slowly turned to dark violet. After stirring for one hour, the solution was concentrated to $c a .1 \mathrm{~mL}$. Slow addition of diethyl ether $(10 \mathrm{~mL})$ gave the complex 5a as a dark violet microcrystalline solid, which was filtered off, washed with diethyl ether and dried under vacuum. Yield: $0.052 \mathrm{~g}(93 \%)$. Anal. Calcd for $\mathrm{C}_{34} \mathrm{H}_{42} \mathrm{~F}_{6} \mathrm{Ir}_{3} \mathrm{~N}_{2} \mathrm{~S}_{4}: \mathrm{C}, 30.73 ; \mathrm{H}, 3.19 ; \mathrm{N}, 2.11$. Found: C, 30.63; H, 3.31; N, 2.15. MS (FAB ${ }^{+}$, $\left.\left.\mathrm{CH}_{2} \mathrm{Cl}_{2}, \mathrm{~m} / \mathrm{z}\right): 1183\left(\left[\operatorname{Ir}_{3}\left(\mu-\mathrm{PyS}_{2}\right)_{2}(\operatorname{cod})_{3}\right]^{+}, 100 \%\right), 1073\left[\operatorname{Ir}_{3}\left(\mu-\mathrm{PyS}_{2}\right)_{2}(\operatorname{cod})_{2}\right]^{+}, 18 \%\right) .{ }^{1} \mathrm{H}$ NMR $\left(\mathrm{CDCl}_{3}, 293 \mathrm{~K}\right) \delta: 7,75\left(\mathrm{~d}, 1 \mathrm{H}, \mathrm{J}_{\mathrm{H}-\mathrm{H}}=7.8 \mathrm{~Hz}\right), 7.26\left(\mathrm{t}, 1 \mathrm{H}, \mathrm{J}_{\mathrm{H}-\mathrm{H}}=7.8 \mathrm{~Hz}\right), 7.01(\mathrm{~d}, 1 \mathrm{H}$, $\left.\mathrm{J}_{\mathrm{H}-\mathrm{H}}=8.2 \mathrm{~Hz}\right), 6.87\left(\mathrm{t}, 1 \mathrm{H}, \mathrm{J}_{\mathrm{H}-\mathrm{H}}=8.2 \mathrm{~Hz}\right), 6.41\left(\mathrm{~d}, 1 \mathrm{H}, \mathrm{J}_{\mathrm{H}-\mathrm{H}}=7.3 \mathrm{~Hz}\right), 6.31\left(\mathrm{~d}, 1 \mathrm{H}, \mathrm{J}_{\mathrm{H}-\mathrm{H}}=8.1\right.$ Hz) $\left(\mathrm{PyS}_{2}\right.$ ligands), $6.26(\mathrm{~m}, 2 \mathrm{H},=\mathrm{CH}), 5.55(\mathrm{~m}, 1 \mathrm{H},=\mathrm{CH}), 5.15(\mathrm{~m}, 1 \mathrm{H},=\mathrm{CH}), 5.05(\mathrm{~m}, 1 \mathrm{H}$, 
$=\mathrm{CH}), 4.95(\mathrm{~m}, 1 \mathrm{H},=\mathrm{CH}), 4.45(\mathrm{~m}, 1 \mathrm{H},=\mathrm{CH}), 4.35(\mathrm{~m}, 1 \mathrm{H},=\mathrm{CH}), 4.15(\mathrm{~m}, 2 \mathrm{H},=\mathrm{CH}), 3.95$ $(\mathrm{m}, 1 \mathrm{H},=\mathrm{CH}), 3.65(\mathrm{~m}, 1 \mathrm{H},=\mathrm{CH}), 3.2-1.5\left(\mathrm{~m}, 24 \mathrm{H}, \mathrm{CH}_{2}\right)(\mathrm{cod}$ ligands $) . \Lambda_{\mathrm{M}}\left(\Omega^{-1} \mathrm{~cm}^{2} \mathrm{~mol}^{-1}\right)$ : 106 (acetone, $4.7510^{-4} \mathrm{M}$ ).

Method B. A solution of $\mathrm{AgBF}_{4}(0.020 \mathrm{~g}, 0.102 \mathrm{mmol})$ in a $1: 1$ acetonedichloromethane mixture $(10 \mathrm{~mL})$ was slowly added to a solution of $\left[\operatorname{Ir}_{4}(\mu \text {-PyS})_{2}(\operatorname{cod})_{4}\right]$ $(0.076 \mathrm{~g}, 0.051 \mathrm{mmol})$ in dichloromethane $(10 \mathrm{~mL})$ with exclusion of light. The initial green mixture gradually turned dark violet within approximately 15 minutes. The solution was filtered through celite to remove metallic silver, and the filtrate concentrated under vacuum to ca. $1 \mathrm{~mL}$. Slow addition of pentane $(10 \mathrm{~mL})$ gave $\mathbf{5 b}$ as dark violet microcrystals, which were filtered off, washed with pentane and dried under vacuum. Yield: $0.045 \mathrm{~g}$ (75\%). Anal. Calcd for $\mathrm{C}_{34} \mathrm{H}_{42} \mathrm{BF}_{4} \mathrm{Ir}_{3} \mathrm{~N}_{2} \mathrm{~S}_{4}$ : C, 32.14; H, 3.33; N, 2.21. Found: C, 32.19; H, 3.35; N, 2.17. $\Lambda_{M}$ $\left(\Omega^{-1} \mathrm{~cm}^{2} \mathrm{~mol}^{-1}\right): 132$ (acetone, $\left.4.5610^{-4} \mathrm{M}\right)$.

$\left[\operatorname{Ir}_{\mathbf{3}}\left(\boldsymbol{\mu}-\mathbf{P y S}_{2}\right)_{2}(\mathbf{t f b b})_{3}\right] \mathbf{B F}_{4}(\mathbf{6})$. A solution of $\mathrm{AgBF}_{4}(0.018 \mathrm{~g}, 0.094 \mathrm{mmol})$ in acetone $(5 \mathrm{~mL})$ was added over a green suspension of $\left[\mathrm{Ir}_{4}\left(\mu-\mathrm{PyS}_{2}\right)_{2}(\mathrm{tfbb})_{4}\right](4)(0.092 \mathrm{~g}, 0.047 \mathrm{mmol})$ in dichloromethane $(10 \mathrm{~mL})$. The brown-green suspension so formed was stirred for four hours and then filtered through kieselguhr to remove the metallic silver. Concentration under vacuum to ca. $1 \mathrm{~mL}$ and slow addition of diethyl ether $(5 \mathrm{~mL})$ gave 7 as a dark green powder which was filtered off, washed with diethyl ether and dried under vacuum. Yield: $0.066 \mathrm{~g}$ (54\%). Anal. Calcd for $\mathrm{C}_{46} \mathrm{H}_{24} \mathrm{BF}_{16} \mathrm{Ir}_{3} \mathrm{~N}_{2} \mathrm{~S}_{4}: \mathrm{C}, 34.01 ; \mathrm{H}, 1.49 ; \mathrm{N}, 1.72$. Found: C, 33.98; H, 1.32; N, 1.73. MS $\left(\mathrm{FAB}^{+}, \mathrm{CH}_{2} \mathrm{Cl}_{2}, \mathrm{~m} / \mathrm{z}\right): 1956\left(\left[\operatorname{Ir}_{4}\left(\mu-\mathrm{PyS}_{2}\right)_{2}(\mathrm{tfbb})_{4}\right]^{+}, 98 \%\right), 1537\left(\left[\operatorname{Ir}_{3}(\mu-\right.\right.$ $\left.\left.\left.\mathrm{PyS}_{2}\right)_{2}(\mathrm{tfbb})_{3}\right]^{+}, 100 \%\right), 1311\left(\left[\operatorname{Ir}_{3}\left(\mu-\mathrm{PyS}_{2}\right)_{2}(\mathrm{tfbb})_{2}\right]^{+}, 15 \%\right) .{ }^{1} \mathrm{H} \mathrm{NMR}\left(\mathrm{CDCl}_{3}, 293 \mathrm{~K}\right) \delta: 7.40$ $\left(\mathrm{dd}, 1 \mathrm{H}, \mathrm{J}_{\mathrm{HH}}=8.1 \mathrm{~Hz}, \mathrm{~J}_{\mathrm{HH}}=1.2 \mathrm{~Hz}\right), 7.14\left(\mathrm{dd}, 1 \mathrm{H}, \mathrm{J}_{\mathrm{HH}}=7.8 \mathrm{~Hz}\right), 7.05\left(\mathrm{t}, 1 \mathrm{H}, \mathrm{J}_{\mathrm{H}-\mathrm{H}}=8.0 \mathrm{~Hz}\right)$, $6.94\left(\mathrm{t}, 1 \mathrm{H}, \mathrm{J}_{\mathrm{H}-\mathrm{H}}=8.2 \mathrm{~Hz}\right), 6.67\left(\mathrm{dd}, 1 \mathrm{H}, \mathrm{J}_{\mathrm{H}-\mathrm{H}}=8.2 \mathrm{~Hz}, \mathrm{~J}_{\mathrm{H}-\mathrm{H}}=1.2 \mathrm{~Hz}\right), 6.63\left(\mathrm{dd}, 1 \mathrm{H}, \mathrm{J}_{\mathrm{H}-\mathrm{H}}=8.0\right.$ $\left.\mathrm{Hz}, \mathrm{J}_{\mathrm{H}-\mathrm{H}}=1.2 \mathrm{~Hz}\right)\left(\mathrm{PyS}_{2}\right.$ ligands), $6.40(\mathrm{~m}, 1 \mathrm{H}, \mathrm{CH}), 6.30(\mathrm{~m}, 1 \mathrm{H}, \mathrm{CH}), 6.24(\mathrm{~m}, 1 \mathrm{H}, \mathrm{CH})$, $6.14(\mathrm{~m}, 1 \mathrm{H}, \mathrm{CH}), 6.08(\mathrm{~m}, 1 \mathrm{H}, \mathrm{CH}), 5.87(\mathrm{~m}, 1 \mathrm{H}, \mathrm{CH}), 5.70(\mathrm{~m}, 1 \mathrm{H},=\mathrm{CH}), 5.65(\mathrm{~m}, 1 \mathrm{H}$, $=\mathrm{CH}), 5.49(\mathrm{~m}, 1 \mathrm{H},=\mathrm{CH}), 5.20(\mathrm{~m}, 1 \mathrm{H},=\mathrm{CH}), 5.09(\mathrm{~m}, 1 \mathrm{H},=\mathrm{CH}), 4.82(\mathrm{~m}, 2 \mathrm{H},=\mathrm{CH}), 4.59$ $(\mathrm{m}, 1 \mathrm{H},=\mathrm{CH}), 4.35(\mathrm{~m}, 1 \mathrm{H},=\mathrm{CH}), 4.25(\mathrm{~m}, 1 \mathrm{H},=\mathrm{CH}), 4.13(\mathrm{~m}, 1 \mathrm{H},=\mathrm{CH}), 3.84(\mathrm{~m}, 1 \mathrm{H}$, $=\mathrm{CH})(\mathrm{tfbb}$ ligands $) . \Lambda_{\mathrm{M}}\left(\Omega^{-1} \mathrm{~cm}^{2} \mathrm{~mol}^{-1}\right): 114$ (acetone, $\left.6.3110^{-4} \mathrm{M}\right)$. 
Crystal Structure Determination of $\left[\operatorname{Ir}_{3}\left(\mu-\mathbf{P y S}_{2}\right)_{2}(\operatorname{cod})_{3}\right] \mathrm{BF}_{4}(5 \mathrm{~b})$. A summary of crystal data and refinement parameters is given in Table 3. Suitable crystals for X-ray diffraction were obtained by slow difusion of $\mathbf{n}$-hexane into a concentrated solution of $\mathbf{5 b}$ in a mixture of dichloromethane/acetone. The selected crystal was a dark-purple irregular block of approximate dimensions $0.24 \times 0.18 \times 0.13 \mathrm{~mm}$. Difraction data were recorded at $173 \mathrm{~K}$ on a Siemens-Stoe AED-2 diffractometer using graphite-monochromated Mo-K $\mathrm{K}_{\alpha}$ radiation $(\lambda=$ $0.71073 \AA$ ). Cell constants were obtained from the least-squares fit on the setting angles of 46 reflections in the range $25 \leq 2 \theta \leq 32^{\circ}$. 7239 reflections with $2 \theta$ in the range $3-50^{\circ}$ were measured using the $\omega / 2 \theta$ scan technique and corrected for Lorentz and polarization effects, and a semiempirical absorption correction, based on azimuthal $\psi$-scans from 12 reflections, was also applied. ${ }^{36}$ Three standard reflections were measured every 55 minutes as a check of crystal and instrument stability; no important variation was observed.

The structure was solved by direct methods (SIR92) ${ }^{37}$ and difference Fourier techniques and refined by full-matrix least-squares on $F^{2}$ (SHELXL97), 38 first with isotropic and then with anisotropic displacement parameters for the non-hydrogen atoms. The hydrogen atoms were introduced in calculated positions or localized in a difference Fourier map (for the olefinic carbon atoms bonded to the metals), and refined riding on the corresponding carbon atoms. The refinement converged at $w R\left(F^{2}\right)=0.0933$ for 436 parameters and 6026 unique reflections. The calculated weighting scheme is $1 /\left[\Sigma^{2}\left(F_{\mathrm{O}}{ }^{2}\right)+\right.$ $\left.(0.0410 \mathrm{P})^{2}+44.61 \mathrm{P}\right]$, where $\mathrm{P}=\left(\operatorname{Max}\left(F_{\mathrm{O}}^{2}, 0\right)+2 F_{\mathrm{c}^{2}}^{2}\right) / 3$. Scattering factors, corrected for anomalous dispersion, as implemented in the refinement program..$^{38}$

Acknowledgements. The generous financial support from Dirección General de Enseñanaza Superior e Investigación (DGES) (Projects PB98-641 and PB94-1186), and a fellowship (M. A. Casado) are gratefully acknowledged.

Supporting Information Available: An X-ray crystallographic file in CIF format for the structure determination of complex $\mathbf{5 b}$. This material is available free of charge via the Internet at http://pubs.acs.org.

\section{References}


(1) (a) Transition Metal Sulfur Chemistry. Biological and Industrial Significance. Stiefel, E. I.; Matsumoto, K. Eds.; American Chemical Society: Washington, DC, 1996. (b) Zanello, P. Coord. Chem. Rev. 1988, 83, 199; 1988, 87, 1. (c) Guittard, J.; Blais, J. C.; Astruc, D.; Valerio, C.; Alonso, E.; Ruiz, J.; Fillaut, J. L. Pure Appl. Chem. 1998, 70, 809. (d) Alonso, E.; Ruiz, J.; Astruc, D. J. Cluster. Sci. 1998, 9, 271. (e) Albano, V. G.; Castellari, C.; Femoni, C.; Iapalucci, M. C.; Longoni, G.; Monari, M.; Rauccio, M.; Zacchini, S. Inorg. Chim. Acta 1999, 291, 372. (f) Prokopuk, N.; Shriver, D. F. Inorg. Chem. 1997, 36, 5609. (g) Scott, M. J.; Holms, R. H. Angew. Chem. Int. Ed. Engl. 1993, 23,564 .

(2) Lemoine, P. Coord. Chem. Rev. 1988, 83, 169; 1982, 47, 55.

(3) Longoni, G.; Femoni, C.; Iapalucci, M. C.; Zanello, P. in Metal Clusters in Chemistry. Braunstein, P.; Oro, L. A.; Raithby, P. Eds.; Wiley-VCH: Weinhein, 1999; Vol. 2.

(4) (a) Tang, Z.; Nomura, Y.; Kuwata, S.; Ishii, Y.; Mizobe, Y.; Hidai, Masanobu. Inorg. Chem. 1998, 37, 4909. (b) Zanello, P. Coord. Chem. Rev. 1988, 83, 199. (c) Connelly, N. G.; Geiger, W.E. Adv. Organomet. Chem. 1985, 24, 87.

(5) Hill, M. G.; Bullock, J. P.; Wilson, T.; Bacon, P.; Blaine, C. A.; Mann, K. R. Inorg. Chim. Acta 1994, 226, 61 .

(6) R. D. Adams in The Chemistry of Metal Cluster Complexes. Shriver, D. F.; Kaesz, H. D.; Adams, R. D. Eds.; VCH: Weinhein, 1990, Ch. 3.

(7) (a) Mashima, K.; Nakano, H.; Nakamura, A. Inorg. Chem. 1996, 35, 9083. (b) Nakano, H.; Nakamura, A.; Mashima, K. Inorg. Chem. 1996, 35, 4007. (c) Uang, R. -H.; Chan, C. -K.; Peng, S. -M.; Che, C. -M. J. Chem. Soc., Chem. Commun. 1994, 2561. (d) Balch, A. L. Prog. Inorg. Chem. 1994, 41, 239.

(8) (a) Kawamura, T.; Maeda, M.; Miyamoto, M.; Usami, H.; Imaeda, K.; Ebihara, M. J. Am. Chem. Soc. 1998, 120, 8136. (b) Best, S. P.; Clark, R. J. H.; Nightingale, A. J. Inorg. Chem. 1990, 29, 1383. (c) Poblet, J. M.; Bernard, M. Inorg. Chem. 1988, 27, 2935, and references therein. (d) Chavan, M. Y.; Zhu, T. P.; Lin, X. Q.; Ahsan, M. Q.; Bear, J. L.; Kadish, K. M. Inorg. Chem. 1984, 23, 4538. 
(9) (a) Connelly, N. G.; Hayward, O. D.; Klangsinsirikul, P.; Orpen A. G.; Rieger, P. H. Chem. Commun. 2000, 963. (b) Jiménez, M. V.; Sola, E.; López, J. A.; Lahoz, F. J.; Oro, L. A. Chem. Eur. J. 1998, 4, 1398. (c) Tejel, C.; Ciriano, M. A.; López, J. A.; Lahoz, F. J.; Oro, L. A. Organometallics 1997, 16, 4718. (d) Connelly, N. G.; Hopkins, P. M.; Orpen, A. G.; Rosair, G. M.; Viguri, F. J. Chem. Soc. Dalton Trans. 1992, 2907. (e) Bruno, G.; Tresoldi, G.; Lo Schiavo, S.; Sergi, S.; Piraino, P. Inorg. Chim. Acta 1992, 197, 9. (f) Brauns, T.; Carriedo, C.; Cockayne, J. S.; Connelly, N. G.; Garcia Hebrosa, G.; Orpen, A. G. J. Chem. Soc. Dalton Trans. 1989, 2049. (g) Boyd, D. C.; Rodman, G. S.; Mann, K. R. J. Am. Chem. Soc. 1986, 108, 1779.

(10) Boyd, D. C.; Connelly, N. G.; Herbosa, G. G.; Hill, M. G.; Mann, K. R.; Mealli, C.; Orpen, A. G.; Richardson, K. E.; Rieger, P. H. Inorg. Chem. 1994, 33, 960.

(11) Winter, R.; Pierce, D. T.; Geiger, W. E.; Lynch, T. J. J. Chem. Soc., Chem. Commun. 1994, 1949.

(12) Villarroya, B. E.; Oro, L. A.; Lahoz, F. J.; Edwards, A. J.; Ciriano, M. A.; Alonso, P. J.; Tiripicchio, A.; Tiripicchio-Camellini, M. Inorg. Chim. Acta 1996, 250, 241.

(13) Oro, L. A.; Ciriano, M. A.; Pérez-Torrente, J. J.; Villarroya, B. E. Coord. Chem. Rev. 1999, 193-195, 941.

(14) Pérez-Torrente, J. J.; Casado, M. A.; Ciriano, M. A.; Lahoz, F. J.; Oro, L. A. Inorg. Chem. 1996, 35, 1782 .

(15) (a) Gagné R. R.; Spiro, C. L.; Smith, T. J.; Hamann, C. A.; Thies, W. R.; Shiemke, A. K. J. Am. Chem. Soc. 1981, 103, 4073. (b) Cayton, R. H.; Chisholm, M. H.; Huffman, J. C.; Lobkovsky, E. B. J. Am. Chem. Soc. 1991, 113, 8709.

(16) Eberson, L., Larsson, B. Acta Chem. Scand, Ser. B 1987, 41, 367.

(17) Connelly, N. G.; Geiger, W. E. Chem. Rev. 1996, 96, 877.

(18) Casado, M. A.; Pérez-Torrente, J. J.; Ciriano, M. A.; Oro, L. A.; Edwards, A. J.; Lahoz, F. J. Cryst. Eng. Comm. 2000, 023.

(19) Casado, M. A.; Pérez-Torrente, J. J.; López, J. A.; Ciriano, M. A.; Lahoz, F. J.; Oro, L. A. Inorg. Chem. 1999, 38, 2482.

(20) Sutherland, B. R.; Cowie, M. Organometallics 1985, 4, 1801. 
(21) Coleman, A. W.; Eadie, D. T.; Stobart, S. R.; Zaworotko, M. J.; Atwood, J. L. J. Am. Chem. Soc. 1982, 104, 922.

(22) Boyd, D. C.; Szalapski, R.; Mann, K. R. Organometallics 1989, 8, 790.

(23) (a) Mealli, C.; Proserpio, D. M. J. Chem. Ed. 1990, 67, 399. (b) Hoffmann, R. J. Chem. Phys. 1963, 39, 1397. (c) Hoffmann, R.; Lipscomb, W. N. J. Chem. Phys. 1962, 36, 2179. (d) Hoffmann, R.; Lipscomb, W. N. J. Chem. Phys. 1962, 36, 2872.

(24) García, M. P.; Jiménez, M. V.; Oro, L. A.; Lahoz, F. J.; Casas, J. M.; Alonso, P. J. Organometallics 1993, 12, 3257.

(25) Hay-Motherwell, R. S.; Koschmieder, S. U.; Wilkinson, G.; Hussain-Bates, B.; Hursthouse, M. B. J. Chem. Soc., Dalton Trans 1991, 2821.

(26) Connelly, N. G.; Finn, C. J.; Freeman, M. J.; Orpen, A. G.; Stirling, J. J. Chem. Soc., Chem. Commun. 1984, 1025.

(27) Connelly, N. G.; Loyns, A. C.; Fernandez, M. J.; Modrego, J.; Oro, L. A. J. Chem. Soc., Dalton Trans 1989, 683.

(28) Connelly, N. G.; Loyns, A. C.; Ciriano, M. A.; Fernández, M. J.; Oro, L. A.; Villarroya, B. E. J. Chem. Soc. Dalton Trans. 1989, 689.

(29) García, M. P.; Jiménez, M. V.; Oro L. A.; Lahoz, F. J.; Alonso P. J. Angew. Chem. Int. Ed. Engl. 1992, 31, 1527.

(30) Fjeldsted, D. O. K.; Stobart, S. R. J. Chem. Soc., Chem. Commun. 1985, 908.

(31) Kanematsu, N.; Ebihara, M.; Kawamura, T. Inorg. Chim. Acta 1999, 292, 244.

(32) (a) Bosnich, B. Inorg. Chem. 1999, 38, 2554. (b) Heyduk, A. F.; Nocera, D. G. J. Am. Chem. Soc. 2000, 122, 9415.

(33) Smart, J. C.; Pinsky, B. L. J. Am. Chem. Soc. 1980, 102, 1009.

(34) Usón, R.; Oro, L. A.; Carmona, D.; Esteruelas, M. A.; Foces-Foces, C; Cano, F. H.; García-Blanco, S.; Vázquez de Miguel, A. J. Organomet. Chem. 1984, 273, 111.

(35) Baker, T.; Doherty, W. P. Jr.; Kelley, W. S.; Newmeyer, W.; Rogers, J. E.; Spalding, R. E.; Walter, R. I. J. Org. Chem. 1965, 30, 3714.

(36) North, A. C. T.; Phillips, D. C.; Mathews, F. S. Acta Crystallogr. 1968, A24, 351. 
(37) Altomare, A.; Cascarano, G.; Giacovazzo, C.; Guagliardi, A. J. Appl. Cryst. 1994, 27, 435.

(38) Sheldrick, G. M. SHELX97; University of Göttingen: Germany, 1997. 
Table 1. Redox potentials ( $\mathrm{E}^{\mathrm{o}} \mathrm{vs} \mathrm{SCE}$, in $\mathrm{V}$ ) and peak-to-peak separation $(\Delta \mathrm{Ep}$ in $\mathrm{mV}$ ) for the complexes $\left.\left[\mathrm{M}_{4}\left(\mu-\mathrm{pyS}_{2}\right)_{2} \text { (dilolefin) }\right)_{4}\right]$ in $0.1 \mathrm{M} \mathrm{TBAH}-\mathrm{CH}_{2} \mathrm{Cl}_{2}$ at $100 \mathrm{mVs}^{-1}$.

\begin{tabular}{|c|c|c|c|c|}
\hline & \multicolumn{2}{|c|}{$\left[\mathrm{M}_{4}\right] \rightarrow\left[\mathrm{M}_{4}\right]^{+}$} & \multicolumn{2}{|c|}{$\left[\mathrm{M}_{4}\right]^{+} \rightarrow\left[\mathrm{M}_{4}\right.$} \\
\hline Complex & $\mathrm{E}^{\mathrm{O}}(\mathrm{V})$ & $\Delta \mathrm{Ep}(\mathrm{mV})$ & $\mathrm{E}^{\mathrm{O}}(\mathrm{V})$ & $\Delta \mathrm{Ep}$ \\
\hline$\left[\mathrm{Rh}_{4}\left(\mu-\mathrm{pyS}_{2}\right)_{2}(\operatorname{cod})_{4}\right](\mathbf{1})$ & 0.16 & 63 & 0.58 & 70 \\
\hline$\left[\mathrm{Rh}_{4}\left(\mu-\mathrm{pyS}_{2}\right)_{2}(\mathrm{tfb})_{4}\right](\mathbf{2})$ & 0.37 & 80 & 0.79 & 80 \\
\hline$\left[\operatorname{Ir}_{4}\left(\mu-\mathrm{pyS}_{2}\right)_{2}(\operatorname{cod})_{4}\right](\mathbf{3})$ & 0.08 & 79 & 0,53 & 80 \\
\hline$\left[\operatorname{Ir}_{4}\left(\mu-\mathrm{pyS}_{2}\right)_{2}(\mathrm{tfb})_{4}\right](4)$ & 0.19 & 90 & & \\
\hline
\end{tabular}


Table 2. Selected Bond Distances and Angles for $\left[\operatorname{Ir}_{3}\left(\mu-\mathrm{PyS}_{2}\right)_{2}(\operatorname{cod})_{3}\right] \mathrm{BF} \mathrm{F}_{4}(\mathbf{5 b})$.

$\begin{array}{llll}\operatorname{Ir}(1)-\operatorname{Ir}(2) & 2.9509(6) & \operatorname{Ir}(2) \ldots \operatorname{Ir}(3) & 3.8633(8) \\ \operatorname{Ir}(1)-\mathrm{S}(1) & 2.442(3) & \operatorname{Ir}(2)-\mathrm{S}(2) & 2.406(2) \\ \operatorname{Ir}(1)-\mathrm{S}(4) & 2.336(2) & \operatorname{Ir}(2)-\mathrm{S}(4) & 2.377(2) \\ \operatorname{Ir}(1)-\mathrm{N}(1) & 2.057(7) & \operatorname{Ir}(2)-\mathrm{N}(2) & 2.096(7) \\ \operatorname{Ir}(1)-\mathrm{C}(11) & 2.205(9) & \operatorname{Ir}(2)-\mathrm{C}(19) & 2.219(9) \\ \operatorname{Ir}(1)-\mathrm{C}(12) & 2.211(9) & \operatorname{Ir}(2)-\mathrm{C}(20) & 2.207(9) \\ \operatorname{Ir}(1)-\mathrm{C}(15) & 2.172(9) & \operatorname{Ir}(2)-\mathrm{C}(23) & 2.190(10) \\ \operatorname{Ir}(1)-\mathrm{C}(16) & 2.163(10) & \operatorname{Ir}(2)-\mathrm{C}(24) & 2.182(10) \\ \operatorname{Ir}(3)-\mathrm{S}(2) & 2.347(2) & \operatorname{Ir}(3)-\mathrm{S}(3) & 2.327(3) \\ \operatorname{Ir}(3)-\mathrm{C}(27) & 2.138(10) & \operatorname{Ir}(3)-\mathrm{C}(31) & 2.170(10) \\ \operatorname{Ir}(3)-\mathrm{C}(28) & 2.162(10) & \operatorname{Ir}(3)-\mathrm{C}(32) & 2.148(10) \\ \operatorname{S}(1)-\mathrm{C}(1) & 1.739(10) & \mathrm{S}(2)-\mathrm{C}(5) & 1.774(10) \\ \operatorname{S}(3)-\mathrm{C}(6) & 1.745(10) & \mathrm{S}(4)-\mathrm{C}(10) & 1.781(10)\end{array}$

$\begin{array}{llll}\operatorname{Ir}(2)-\operatorname{Ir}(1)-\mathrm{S}(1) & 127.58(7) & \operatorname{Ir}(1)-\operatorname{Ir}(2)-\mathrm{S}(2) & 82.04(6) \\ \operatorname{Ir}(2)-\operatorname{Ir}(1)-\mathrm{S}(4) & 51.87(6) & \operatorname{Ir}(1)-\operatorname{Ir}(2)-\mathrm{S}(4) & 50.62(6) \\ \operatorname{Ir}(2)-\operatorname{Ir}(1)-\mathrm{N}(1) & 77.4(2) & \operatorname{Ir}(1)-\operatorname{Ir}(2)-\mathrm{N}(2) & 86.5(2) \\ \operatorname{Ir}(2)-\operatorname{Ir}(1)-\mathrm{CC}(1)^{\mathrm{a}} & 113.5(3) & \operatorname{Ir}(1)-\operatorname{Ir}(2)-\mathrm{CC}(3)^{\mathrm{a}} & 99.8(3) \\ \operatorname{Ir}(2)-\operatorname{Ir}(1)-\mathrm{CC}(2)^{\mathrm{a}} & 115.0(3) & \operatorname{Ir}(1)-\operatorname{Ir}(2)-\mathrm{CC}(4)^{\mathrm{a}} & 158.7(3) \\ \mathrm{S}(1)-\operatorname{Ir}(1)-\mathrm{S}(4) & 96.05(9) & \mathrm{S}(2)-\operatorname{Ir}(2)-\mathrm{S}(4) & 126.12(8) \\ \mathrm{S}(1)-\operatorname{Ir}(1)-\mathrm{N}(1) & \mathrm{S}(2)-\operatorname{Ir}(2)-\mathrm{N}(2) & 86.4(2) \\ \mathrm{S}(1)-\operatorname{Ir}(1)-\mathrm{CC}(1)^{\mathrm{a}} & 67.7(2) & \mathrm{S}(2)-\operatorname{Ir}(2)-\mathrm{CC}(3)^{\mathrm{a}} & 100.4(3) \\ \mathrm{S}(1)-\operatorname{Ir}(1)-\mathrm{CC}(2)^{\mathrm{a}} & 104.9(3) & \mathrm{S}(2)-\operatorname{Ir}(2)-\mathrm{CC}(4)^{\mathrm{a}} & 117.9(3) \\ \mathrm{S}(4)-\operatorname{Ir}(1)-\mathrm{N}(1) & 102.2(3) & \mathrm{S}(4)-\operatorname{Ir}(2)-\mathrm{N}(2) & 68.9(2) \\ \mathrm{S}(4)-\operatorname{Ir}(1)-\mathrm{CC}(1)^{\mathrm{a}} & 99.3(2) & \mathrm{S}(4)-\operatorname{Ir}(2)-\mathrm{CC}(3)^{\mathrm{a}} & 110.5(3) \\ \mathrm{S}(4)-\operatorname{Ir}(1)-\mathrm{CC}(2)^{\mathrm{a}} & 89.4(3) & \mathrm{S}(4)-\operatorname{Ir}(2)-\mathrm{CC}(4)^{\mathrm{a}} & 108.3(3) \\ \mathrm{N}(1)-\operatorname{Ir}(1)-\mathrm{CC}(1)^{\mathrm{a}} & 161.7(3) & \mathrm{N}(2)-\operatorname{Ir}(2)-\mathrm{CC}(3)^{\mathrm{a}} & 171.3(4)\end{array}$


$\mathrm{N}(1)-\operatorname{Ir}(1)-\mathrm{CC}(2)^{\mathrm{a}}$

88.5(4)

$\mathrm{N}(2)-\operatorname{Ir}(2)-\mathrm{CC}(4)^{\mathrm{a}}$

87.5(4)

Table 2 (Cont.)

$\mathrm{CC}(1)-\operatorname{Ir}(1)-\mathrm{CC}(2)^{\mathrm{a}}$

85.2(4)

$\mathrm{CC}(3)-\operatorname{Ir}(2)-\mathrm{CC}(4)^{\mathrm{a}}$

84.5(4)

$\mathrm{S}(2)-\operatorname{Ir}(3)-\mathrm{S}(3)$

95.35(8)

$\mathrm{S}(3)-\operatorname{Ir}(3)-C C(5)^{\mathrm{a}}$

175.7(3)

$S(2)-\operatorname{Ir}(3)-C C(5)^{a}$

89.0(3)

$S(3)-\operatorname{Ir}(3)-C C(6)^{a}$

88.7(3)

$S(2)-\operatorname{Ir}(3)-C C(6)^{a}$

175.9(3)

$\mathrm{CC}(5)-\operatorname{Ir}(3)-\mathrm{CC}(6)^{\mathrm{a}}$

87.0(4)

${ }^{\mathrm{a}} \mathrm{CC}(\mathrm{n})$

represents the midpoint of a $\mathrm{C}=\mathrm{C}$ olefinic bond $(\mathrm{n}=1, \mathrm{C}(11)-\mathrm{C}(12) ; \mathrm{n}=2, \mathrm{C}(15)-\mathrm{C}(16) ; \mathrm{n}=$ 3, $C(19)-C(20) ; n=4, C(23)-C(24) ; n=5, C(27)-C(28) ; n=6, C(31)-C(32)$.

Table 3. Crystallographic Data for $\left[\operatorname{Ir}_{3}\left(\mu-\mathrm{PyS}_{2}\right)_{2}(\operatorname{cod})_{3}\right] \mathrm{BF}_{4}(\mathbf{5 b})$.

$\begin{array}{ll}\text { chemical formula } & \mathrm{C}_{34} \mathrm{H}_{42} \mathrm{BF}_{4} \mathrm{Ir}_{3} \mathrm{~N}_{2} \mathrm{~S}_{4} \\ \text { formula weight } & 1270.35 \\ \text { temp, K } & 173(2) \\ \text { space group } & P 2{ }_{1} / \mathrm{c}(\text { no 14) } \\ a, \AA & 7.9234(9) \\ b, \AA & 22.002(4) \\ c, \AA & 19.786(3) \\ \beta, \text { deg } & 96.395(14) \\ V, \AA & 3427.8(9) \\ Z & 4 \\ \lambda & 0.71073 \AA \\ \rho(\text { calcd }), \mathrm{g} \mathrm{cm}^{-3} & 2.462 \\ \mu(\mathrm{Mo} \mathrm{K \alpha}), \mathrm{mm}^{-1} & 11.914 \\ R(F)\left[F^{2}>2 \sigma\left(F^{2}\right)\right]^{\mathrm{a}} & 0.0354 \\ w R\left(F^{2}\right)[\text { all data }]^{\mathrm{b}} & 0.0933\end{array}$


${ }^{\mathrm{a}} R(F)=\Sigma\left\|F_{o}|-| F_{\mathrm{c}}\right\| / \Sigma\left|F_{\mathrm{o}}\right|$, for 5057 observed reflections. ${ }^{\mathrm{b}} w R\left(F^{2}\right)=\left(\Sigma\left[w\left(F_{o}{ }^{2}-\right.\right.\right.$ $\left.\left.\left.F_{c}^{2}\right)^{2}\right] / \Sigma\left[w\left(F_{o}^{2}\right)^{2}\right]\right)^{1 / 2}$.

\section{Captions to the Figures}

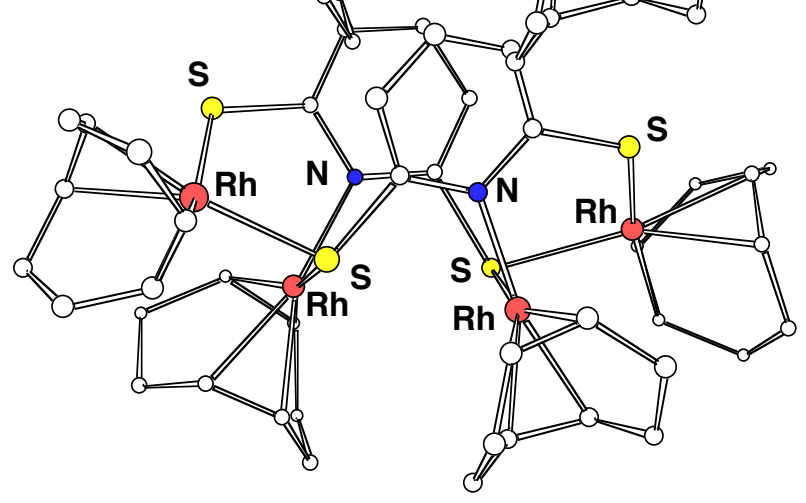

Figure 1. Chem3D representation of the molecular structure of $\left[\operatorname{Rh}_{4}\left(\mu-p_{y} S_{2}\right)_{2}(\operatorname{cod})_{4}\right](\mathbf{1})$.

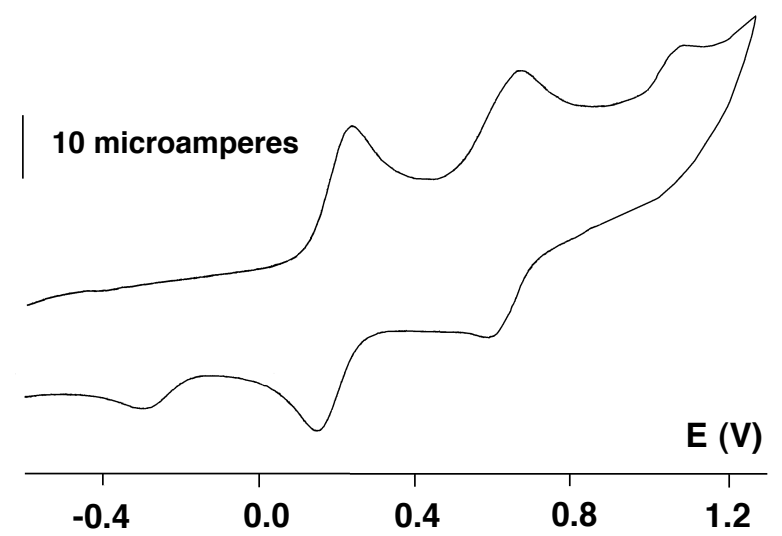

Figure 2. Cyclic voltammogram of $\left[\operatorname{Ir}_{4}\left(\mu-\mathrm{PyS}_{2}\right)_{2}(\mathrm{tfbb})_{4}\right]$ (4) measured in $\mathrm{CH}_{2} \mathrm{Cl}_{2} / 0.1 \mathrm{M}$ TBAH at a platinum disk electrode at $100 \mathrm{mVs}^{-1}$. 

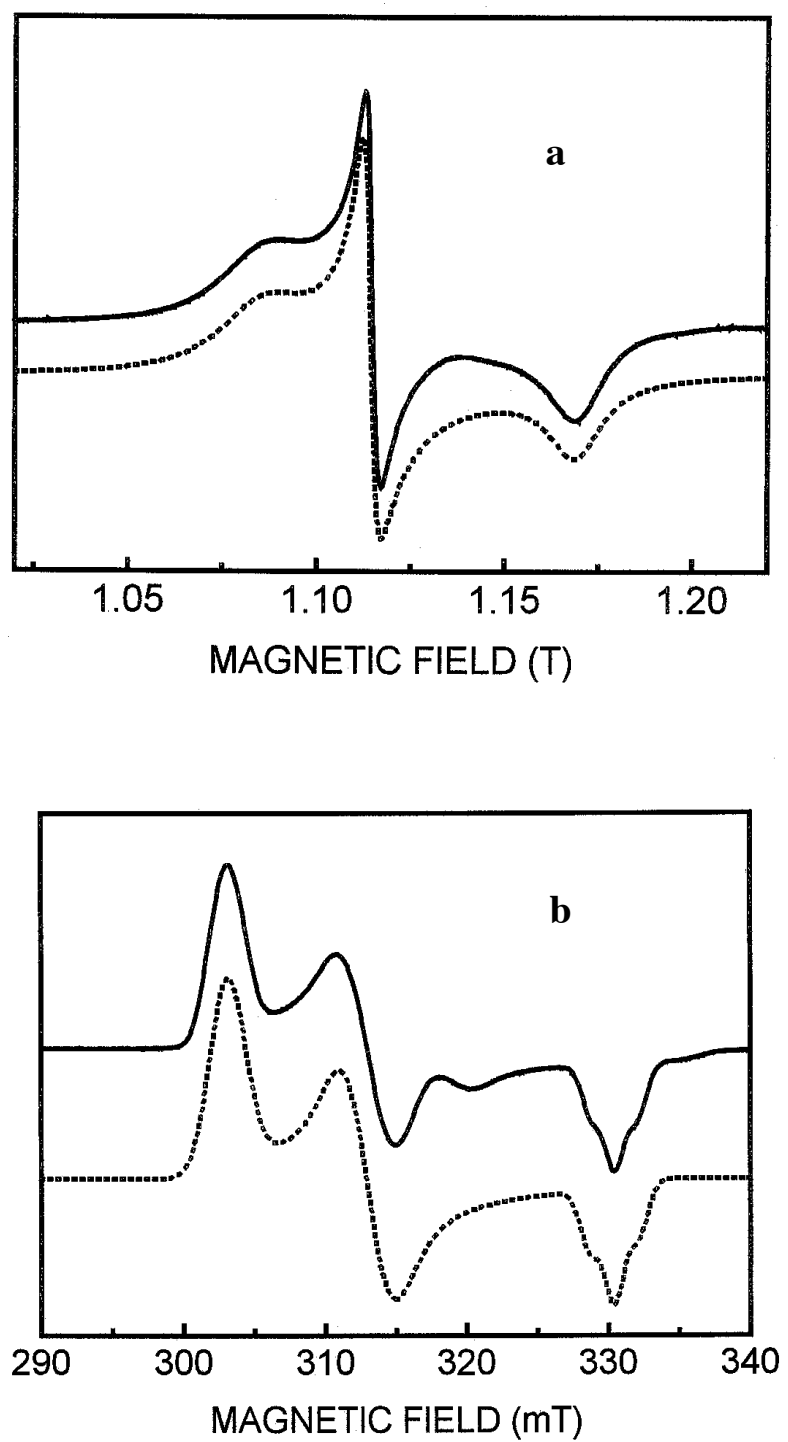

Figure 3. a) Q-band EPR spectrum of a polycrystalline sample of $\left[\mathrm{Rh}_{4}\left(\mu-\mathrm{PyS}_{2}\right)_{2}(\operatorname{cod})_{4}\right] \mathrm{PF}_{6}$ at $90 \mathrm{~K}\left(\mathbf{1 a}^{+}\right)$. b) X-band EPR spectrum of a frozen solution of $\left(\mathbf{1 a}^{+}\right)$at $90 \mathrm{~K}$. The continuous lines correspond to the experimental spectra and the dotted lines to the simulated ones. 


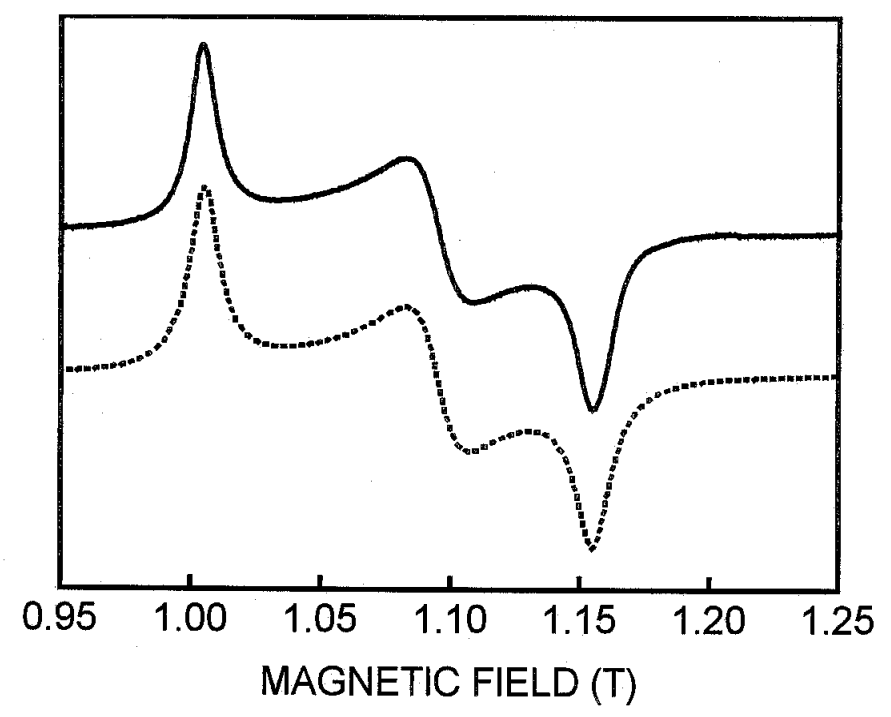

Figure 4. Q-band EPR spectrum of a polycrystalline sample of $\left[\operatorname{Ir}_{4}\left(\mu-\mathrm{PyS}_{2}\right)_{2}(\operatorname{cod})_{4}\right] \mathrm{BF}_{4}\left(3^{+}\right)$ at $90 \mathrm{~K}$.

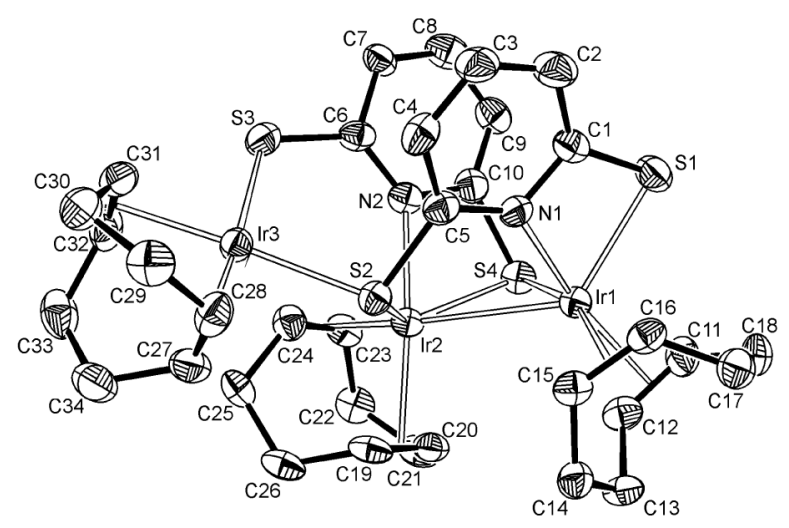

Figure 5. Molecular structure of $\left[\operatorname{Ir}_{3}\left(\mu-\mathrm{PyS}_{2}\right)_{2}(\operatorname{cod})_{3}\right] \mathrm{BF}_{4}(\mathbf{5 b})$. 


$$
\begin{aligned}
& {\left[\operatorname{Ir}_{4}\left(\mu-\mathrm{PyS}_{2}\right)_{2}(\operatorname{cod})_{4}\right] \quad\left(64 \mathrm{e}^{-}\right)} \\
& -1 e^{-} \\
& {\left[\operatorname{Ir}_{4}\left(\mu-\mathrm{PyS}_{2}\right)_{2}(\operatorname{cod})_{4}\right]^{+}\left(63 \mathrm{e}^{-}\right)} \\
& \left(\begin{array}{c}
-1 e^{-} \\
{\left[\operatorname{Ir}_{4}\left(\mu-\mathrm{PyS}_{2}\right)_{2}(\operatorname{cod})_{4}\right]^{2+}}
\end{array}\right) \underset{\left.[\operatorname{lr}(\operatorname{cod})]^{+}\right)}{\longrightarrow} \frac{\left[\operatorname{lr}_{3}\left(\mu-\mathrm{PyS}_{2}\right)_{2}(\operatorname{cod})_{3}\right]^{+}}{\left(50 \mathrm{e}^{-}\right)}
\end{aligned}
$$

Scheme 1

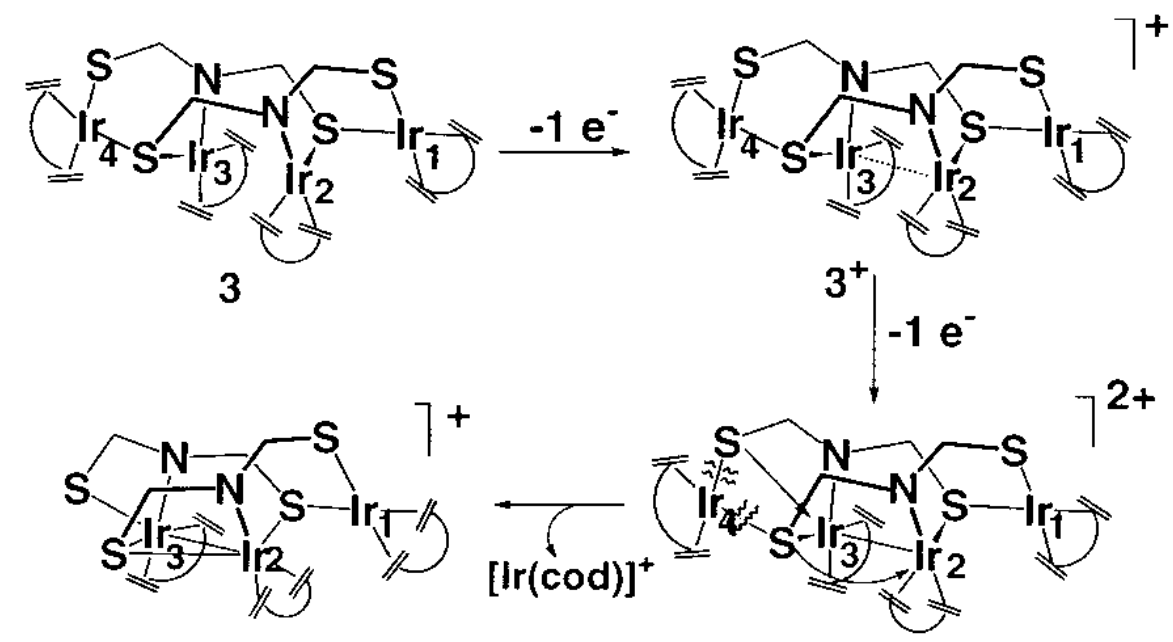

5

Scheme 2 